\title{
Synthesis of Propargylamines by Cross-Dehydrogenative Coupling
}

\author{
Francisco Alonso*, Irene Bosque, Rafael Chinchilla, José Carlos Gonzalez-Gomez, David Guijarro
}

Instituto de Síntesis Orgánica and Departamento de Química Orgánica, Facultad de Ciencias, Universidad de Alicante, Apdo. 99, 03080 Alicante, Spain

\begin{abstract}
Propargylamines are versatile compounds for heterocyclic synthesis, some of which are current drugs prescribed to treat patients with Parkinson's disease. There are different methods to synthesize propargylamines; however, modern chemistry has moved progressively demanding to rely on new strategies that meet the principles of Green Chemistry. In this context, propargylamines are readily accessible by the cross-dehydrogenative coupling (CDC) of two $\mathrm{C}-\mathrm{H}$ bonds (i.e., $\mathrm{NCsp}^{3}-\mathrm{H}$ and $\mathrm{Csp}-\mathrm{H}$ bonds); surely, $\mathrm{CDC}$ can be considered the most atom-economic and efficient manner to form $\mathrm{C}-\mathrm{C}$ bonds. The aim of this review is to provide a comprehensive survey on the synthesis of propargylamines by the CDC of amines and terminal alkynes from three fronts: (a) transition-metal homogeneous catalysis, (b) transition-metal heterogeneous catalysis and (c) photoredox catalysis. A section dealing with the asymmetric synthesis of chiral propargylamines is also included. Special attention is also devoted to the proposed reaction mechanisms.
\end{abstract}

Keywords: asymmetric synthesis, cross-dehydrogenative coupling, green chemistry, homogeneous catalysis, heterogeneous catalysis, photoredox catalysis, propargylamines, tetrahydroisoquinolines.

\section{INTRODUCTION}

Propargylamines are useful synthetic scaffolds broadly exploited as precursors of heterocyclic compounds, such as quinolones [1a], phenanthrolines [1b], pyrroles [1c], pyrrolidines [1d], indolizines [1e] or oxazolidinones [1f], among others [2]. They have also been utilized as starting materials for transition-metal catalyzed $\mathrm{Csp}^{3}-\mathrm{H}$ and $\mathrm{Csp}^{3}-$ Csp activation [3], and as intermediates in the total synthesis of some natural and pharmaceutical products [4]. The propargylamine unit can be found in diverse bioactive compounds [5], some of which have been proven to be potent anti-apoptotic agents that protect neurons against cell death in cellular and animal models of neurodegenerative disorders. Indeed, they have been shown to delay the necessity for symptomatic therapy in untreated Parkinson's disease patients, results that are consistent with the neuroprotection role of this type of compounds [6]. For instance, selegiline (Anipril ${ }^{\circledR}$ ) and rasagiline $\left(\right.$ Azilect $^{\circledR}$ ) are current propargylamine-containing drugs for monotherapy in patients with early Parkinson's disease and for adjunctive therapy in patients with moderate-to-advanced disease [6c]. Pargyline (Eutonyl ${ }^{\circledR}$ ) is an irreversible inhibitor of monoamine oxidase (MAO) with antihypertensive properties [6d] (Figure 1).
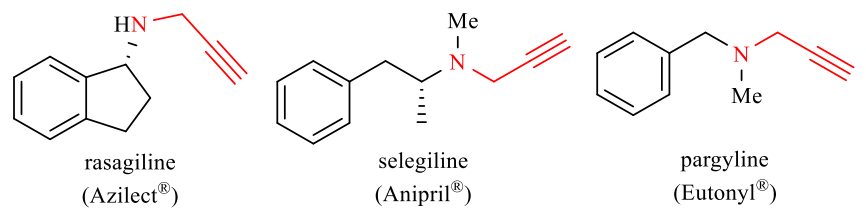

Figure 1. Some examples of bioactive propargylamines.

Standard procedures for the construction of the propargylamine moiety are based on the direct amination of propargyl halides [7a], triflates [7b], phosphates or acetates [7c], or on the more widely practiced addition of alkynylmetal reagents to imines [Scheme 1, eq. (1) and (2), respectively] [8]. The latter option, normally involving stoichiometric amounts of lithium or magnesium acetylides, demands strict control of the reaction conditions and its application is hampered by the presence of reactive functional groups. The metal-catalyzed multicomponent coupling of aldehydes, amines, and alkynes ( $\mathrm{A}^{3}$ coupling) [9] or the nucleophilic substitution of in-situ generated chloromethyl amines catalyzed by copper or silver [Scheme 1 , eq. (3) and (4), respectively] [10] are more interesting approaches.

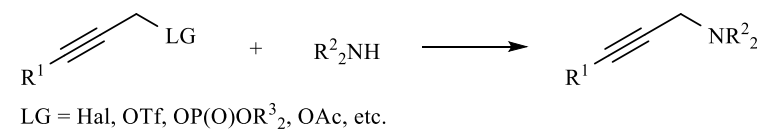

$\mathrm{LG}=\mathrm{Hal}, \mathrm{OTf}, \mathrm{OP}(\mathrm{O}) \mathrm{OR}^{3}{ }_{2}, \mathrm{OAc}$, etc.
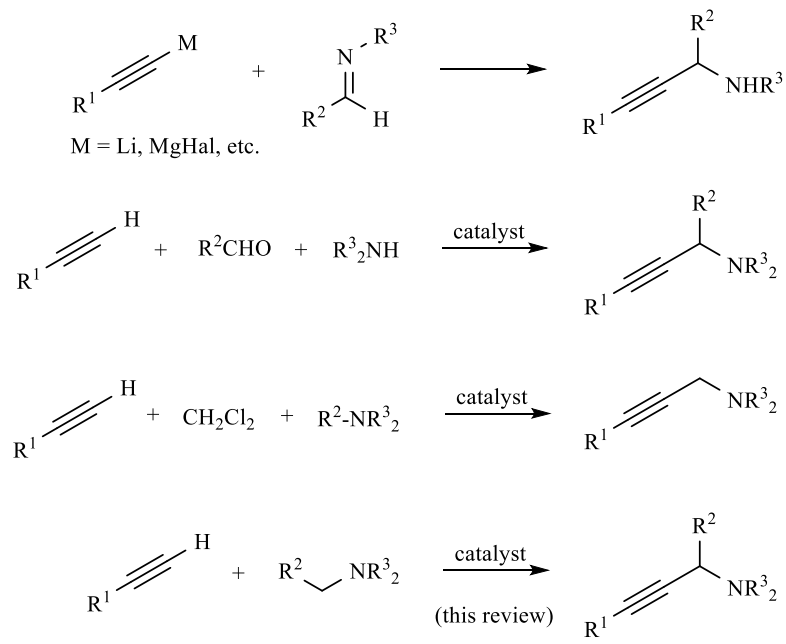

Scheme 1. Some general methods for the synthesis of propargylamines. 
On the other hand, a C-C bond should be ideally built from two $\mathrm{C}-\mathrm{H}$ bonds (Scheme 2). Historically, the oxidative homocoupling of alkynes promoted by copper can be considered the first reaction of this type; originally discovered by Glaser in 1869 utilizing $\mathrm{CuCl}$ and ammonia in the presence of oxygen [11a], it was upgraded almost a century later by Eglinton [11b] [excess of $\mathrm{Cu}(\mathrm{OAc})_{2}$ in $\mathrm{MeOH}-\mathrm{Py}]$ and Hay with the introduction of pyridine or TMEDA (Scheme 3) [11c].

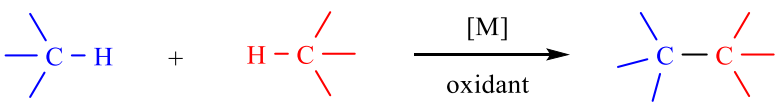

Scheme 2. Carbon-carbon bond formation from C-H bonds.

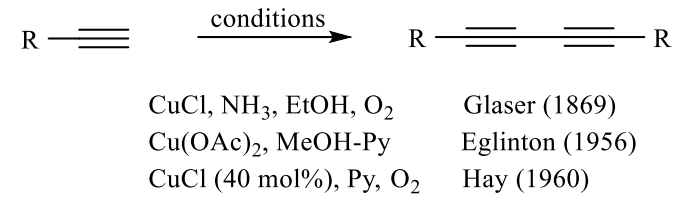

Scheme 3. Oxidative alkyne homocoupling.

The conversion of two C-H (or C-H and Het-H) bonds into a $\mathrm{C}-\mathrm{C}$ (or $\mathrm{C}-\mathrm{Het}$ ) bond is nowadays known as the crossdehydrogenative coupling (CDC). This is a powerful atomeconomy tool to efficiently design organic molecules, that has become one of the most active research areas in chemistry [12]. We present herein a comprehensive review on the synthesis of propargylamines by the catalytic coupling of $\mathrm{Csp}^{3}-\mathrm{H}$ bonds adjacent to nitrogen with $\mathrm{Csp}-\mathrm{H}$ bonds of terminal alkynes [Scheme 1, eq. (5)].

\section{TRANSITION-METAL CATALYSIS}

\subsection{Homogeneous catalysis}

In 1993, Miura et al. published the synthesis of $N$-methyl- $N$ propargylamines from $\mathrm{N}, \mathrm{N}$-dimethylanilines and terminal alkynes catalyzed by $\mathrm{CuCl}_{2}$, under an oxygen atmosphere in acetonitrile (Scheme 4) [13]. Besides using 2 equiv. of the alkyne, the reaction was little selective, producing substantial amounts of the $N$-methyl- and $N$-formyl- $N$ methylanilines as by-products. The reaction mechanism set forth involved the aminomethyl radical of the $\mathrm{N}, \mathrm{N}$ dimethylamine (generated either by one-electron oxidation/deprotonation or by hydrogen abstraction), the corresponding benzyl organocopper and its complex with the arylacetylene. However, the authors stated that the role of the copper species in this reaction was dubious (Scheme 4). This can be considered the first synthesis of propargylamines through CDC. Copper catalysis has been most applied to this reaction ever since.

A major breakthrough was achieved by $\mathrm{Li}$ et al. with the introduction of $\mathrm{CuBr}$ as catalyst and tert-butylhydroperoxide (TBHP) as an oxidant (Scheme 5) [14]. Not only $N, N$ dimethylanilines but other amines also underwent this reaction. The process was especially straightforward in the case of arylacetylenes, whereas the aliphatic counterparts were found to be more reluctant to react. In a tentative reaction mechanism, the participation of an iminium ion complexed to copper was propounded together with the insitu generation of the copper acetylide, followed by coupling of these two intermediates (Scheme 5).
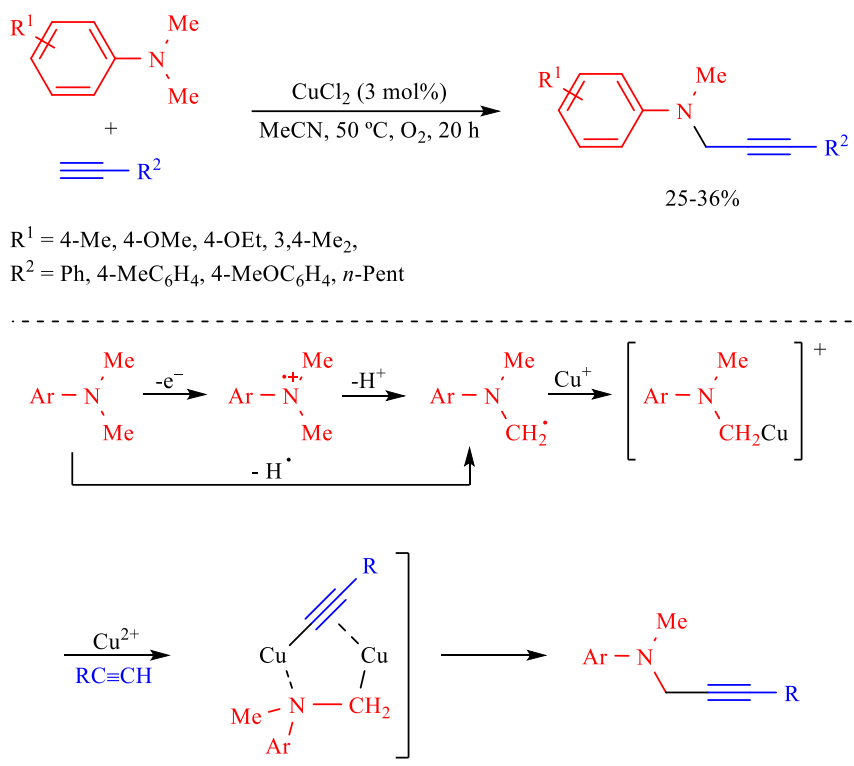

Scheme 4
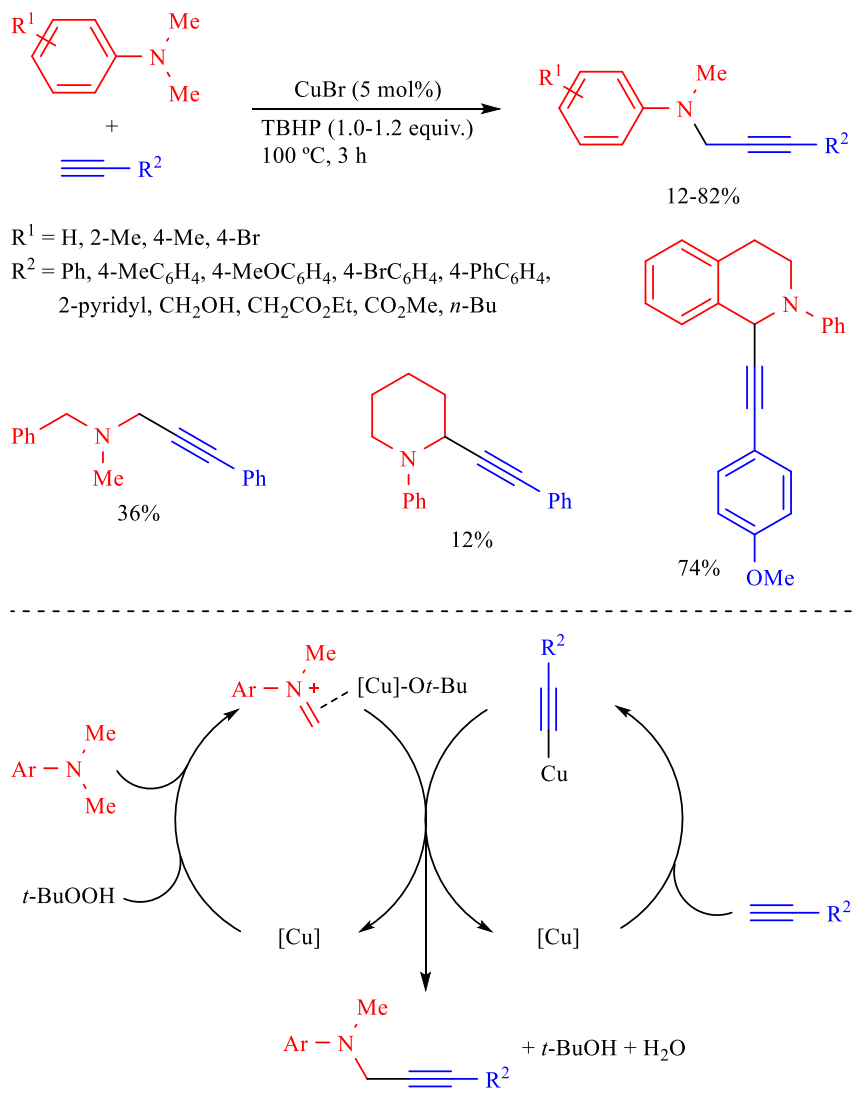

Scheme 5

Fu et al. replaced TBHP by the safer NBS as an alternative oxidant or free radical initiator [15]. The optimized reaction conditions required a larger amount of catalyst $(40 \mathrm{~mol} \%$ $\mathrm{CuBr}$ ) and 2 equiv. of amine in $\mathrm{MeCN}$ as solvent, at $80{ }^{\circ} \mathrm{C}$ under a nitrogen atmosphere (Scheme 6). The procedure was mostly employed in the coupling of tertiary benzylic amines and aromatic alkynes; $N, N$-dimethylanilines as well as aliphatic (non-benzylic) amines were more resistant to react. Lower yields were also attained in the case of aliphatic 
alkynes. The authors proposed that the intermediate amine radical cation was formed by the action of the free radicals derived from NBS on the tertiary amine, followed by hydrogen abstraction to produce the iminium ion, which would, eventually, undergo the attack of the copper acetylide.

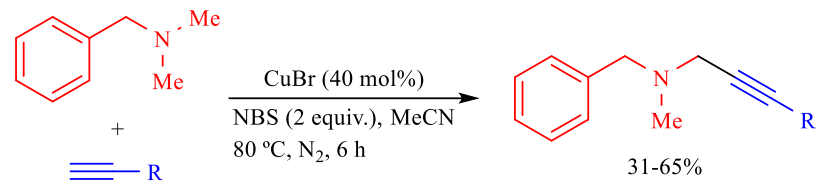

$\mathrm{R}=\mathrm{Ph}, 4-\mathrm{MeC}_{6} \mathrm{H}_{4}, 4-\mathrm{MeOC}_{6} \mathrm{H}_{4}, 2-\mathrm{BrC}_{6} \mathrm{H}_{4}, 4-\mathrm{O}_{2} \mathrm{NC}_{6} \mathrm{H}_{4}$,

1-naphthyl, cyclopropyl, 1-hexyl
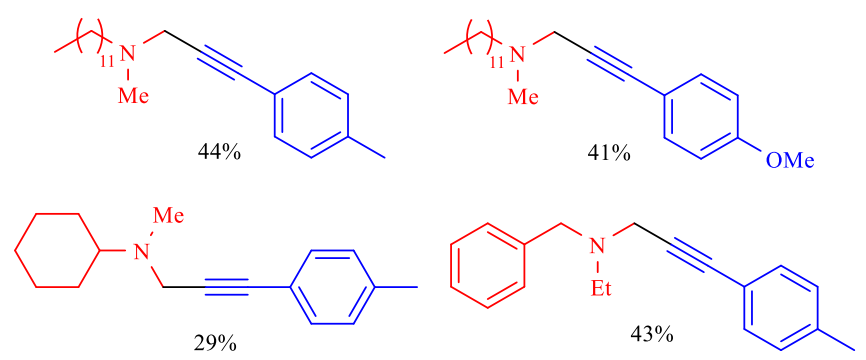

\section{Scheme 6}

Very recently, the same type of tertiary benzylic amines have been coupled with aromatic alkynes employing $\mathrm{Cu}(\mathrm{I})$ complexes of 4,5-bis[(phenylthio/seleno)methyl]-acridine as catalysts [16]. In general, electron-rich substrates led to better yields of the desired propargylamines (Scheme 7). Contrary to the previous catalytic system commented, $\mathrm{N}, \mathrm{N}$ dimethylanilines reacted under equal conditions as the $\mathrm{N}, \mathrm{N}$ dimethylbenzylamines in moderate-to-good yields. Aliphatic (non-benzylic) amines were not covered in this study, whereas the only propargylamine tested derived from an aliphatic alkyne was obtained in modest yield $(46 \%, X=S$; $51 \%, X=\mathrm{Se}$ ). In spite of being a homogeneous catalytic system, it could be recycled in five runs by adding, every time, a fresh lot of reactants to the flask, though with limited effectiveness (73-45\% yield). A close reaction mechanism to that of $\mathrm{Li}$ et al. was invoked.

The alkynylation of aliphatic tertiary amines through CDC was improved by introducing DEAD as a dehydrogenating agent of the amines [17]. In this way, there was no need to exclude air and moisture from the reaction flask, with the reactions proceeding under mild conditions in good-toexcellent yields. Moreover, the method was applicable to the less reactive aliphatic alkynes and trimethylsilylacetylene (Scheme 8). The reaction was advocated to take place through an ionic pair comprised of the iminium cation of the amine and the hydrazine anion derived from DEAD.

The crucial role of the oxidant in these reactions was clearly demonstrated by J.-X. Li et al. in the coupling of TMEDA with terminal alkynes [18]. The expected CDC products were produced when using $\mathrm{CuCl}_{2}(10 \mathrm{~mol} \%)$ in DMSO at 80 ${ }^{\circ} \mathrm{C}$ in air; however, cleavage of the C-C bond of TMEDA took place when switching to TBHP at room temperature, leading to propargylamines derived from a formal alkyne aminomethylation reaction (Scheme 9).
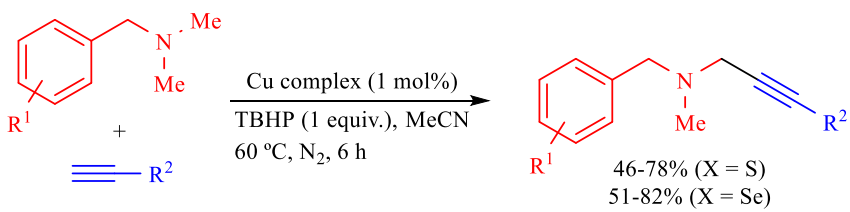

$\mathrm{R}^{1}=\mathrm{Ph}, 4-\mathrm{YC}_{6} \mathrm{H}_{4}(\mathrm{Y}=\mathrm{Me}, \mathrm{MeO}, \mathrm{Cl}, \mathrm{Br}), 3-\mathrm{ClC}_{6} \mathrm{H}_{4}$

$\mathrm{R}^{2}=\mathrm{Ph}, 4-\mathrm{MeC}_{6} \mathrm{H}_{4}, 4-\mathrm{MeOC}_{6} \mathrm{H}_{4}, \mathrm{CF}_{3}, 2$-pyridyl, $n$-Pent

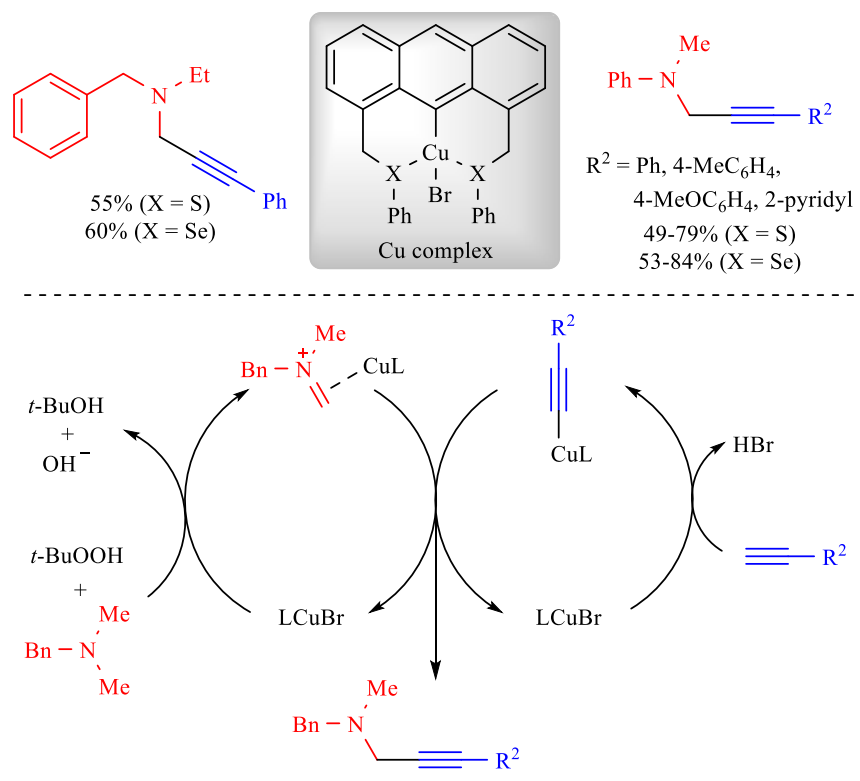

Scheme 7

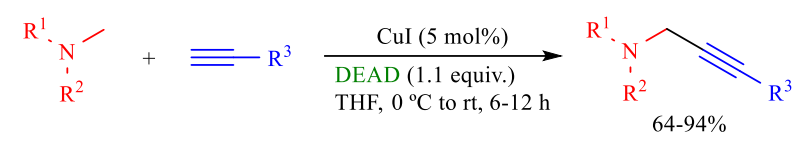

$\mathrm{R}^{1}=\mathrm{Me} ; \mathrm{R}^{2}=c$-hexyl; $\mathrm{R}^{3}=\mathrm{Ph}, 4-\mathrm{MeC}_{6} \mathrm{H}_{4}, 4-\mathrm{MeOC}_{6} \mathrm{H}_{4}, 2-\mathrm{F}_{3} \mathrm{CC}_{6} \mathrm{H}_{4}, 3-\mathrm{FC}_{6} \mathrm{H}_{4}$, 3- $\mathrm{ClC}_{6} \mathrm{H}_{4}, \mathrm{Bn}, \mathrm{PhCH}_{2} \mathrm{CH}_{2}$, 3-pyridyl, 3-thienyl, Bu, TMS

$\mathrm{R}^{1}=\mathrm{Me}, \mathrm{R}^{2}=c$-pentyl, $\mathrm{R}^{3}=\mathrm{Ph}$

$\mathrm{R}^{1}=\mathrm{Me}, \mathrm{R}^{2}=c$-heptyl, $\mathrm{R}^{3}=\mathrm{Ph}$

$\mathrm{R}^{1}=\mathrm{R}^{2}=c$-hexyl, $\mathrm{R}^{3}=\mathrm{Ph}$

$\mathrm{R}^{1}=i-\mathrm{Pr}, \mathrm{R}^{2}=t-\mathrm{Bu}, \mathrm{R}^{3}=\mathrm{Ph}$

$\mathrm{R}^{1}=\mathrm{Me}, \mathrm{R}^{2}=\mathrm{Bn}, \mathrm{R}^{3}=\mathrm{Ph}$

$\mathrm{R}^{1}=\mathrm{Me}, \mathrm{R}^{2}=i-\mathrm{Pr}, \mathrm{R}^{3}=4-\mathrm{Me}\left(\mathrm{CH}_{2}\right)_{4} \mathrm{C}_{6} \mathrm{H}_{4}$

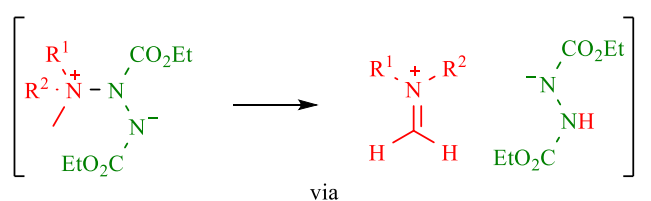

\section{Scheme 8}

In 2011, Bao et al. disclosed the synthesis of $N, N$ dimethylpropargylamines by the $\mathrm{Cu}(\mathrm{II})$-catalyzed $\mathrm{CDC}$ of terminal alkynes and tertiary amine $\mathrm{N}$-oxides, instead of the typically studied tertiary amines [19]. A clear advantage was the fact that the reactions proceeded in the absence of an external oxidant, using $\mathrm{Cu}(\mathrm{acac})_{2}$ in $\mathrm{DME}$ at $110{ }^{\circ} \mathrm{C}$. However, one additional step was required, as the amine $\mathrm{N}$ oxides had to be prepared by amine oxidation; this, together with the usage of two equiv. of the amine $\mathrm{N}$-oxide and the necessity for a nitrogen atmosphere, can be considered the weak points of this approach. Both, aromatic and aliphatic alkynes reacted with excellent functional group compatibility 


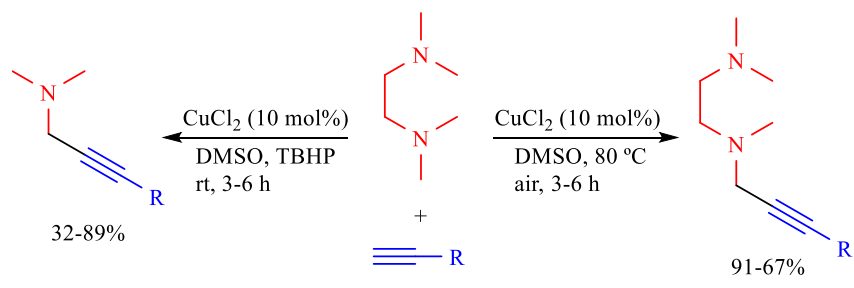

$\mathrm{R}=\mathrm{Ph}, n$ - $\mathrm{Bu}, t-\mathrm{Bu}$, 2-thienyl, 3- $\mathrm{MeC}_{6} \mathrm{H}_{4}, 4-\mathrm{YC}_{6} \mathrm{H}_{4}(\mathrm{Y}=t$ - $\mathrm{Bu}, \mathrm{MeO}, \mathrm{F})$

$\mathrm{Ar}^{-} \stackrel{\mathrm{Ts}}{\mathrm{S}} / \mathrm{y}_{2} \quad \mathrm{Ar}=\mathrm{Ph}, 4-\mathrm{YC}_{6} \mathrm{H}_{4}(\mathrm{Y}=\mathrm{Me}, \mathrm{MeO}, \mathrm{I})$

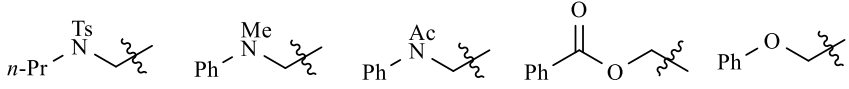<smiles>CC(C)(C)CN1CCCc2ccccc21</smiles><smiles>CC(C)(C)Cn1ccc2ccccc21</smiles><smiles>CCCN1C(=O)c2ccccc2C1=O</smiles>

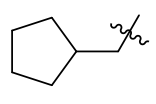

Scheme 9

and in moderate-to-high yields (Scheme 10). Trimethylamine $N$-oxide gave the best results, whereas modest yields were noted for $N$-methylmorpholine $N$-oxide and benzyldimethylamine $N$-oxide. The authors advocated iminium ions coordinated to copper hydroxide and copper acetylide as intermediates.

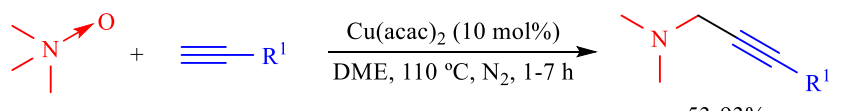

$\mathrm{R}^{1}=\mathrm{Ph}, 4-\mathrm{MeC}_{6} \mathrm{H}_{4}, 4-\mathrm{BrC}_{6} \mathrm{H}_{4}, 4-\mathrm{FC}_{6} \mathrm{H}_{4}, c-\mathrm{Hex}, n-\mathrm{Oct}, \mathrm{PhCH}_{2} \mathrm{CH}_{2}$,<smiles>CC(C)(C)CN1C(=O)c2ccccc2C1=O</smiles><smiles>[R]c1cccc(I)c1</smiles>

$53-93 \%$<smiles>C(C#Cc1ccccc1)#CCN1CCOCC1</smiles>

$\begin{aligned}= & \mathrm{H}, 4-\mathrm{NO}_{2}, 4-\mathrm{OMe}, 4-\mathrm{CO}_{2} \mathrm{Me}, 4-\mathrm{C} \\ & 4-\mathrm{CHO}, 2-\mathrm{CHO}, 2-\mathrm{Br}-4-\mathrm{OMe}\end{aligned}$

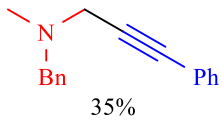

\section{Scheme 10}

The CDC of tertiary amines and terminal alkynes is not limited to copper catalysis; catalytic systems based on iron and zinc have also been shown to be efficient in this transformation. For instance, in 2009, Vogel et al. introduced $\mathrm{FeCl}_{2}$ as an alternative to copper catalysts for the CDC of $\mathrm{N}, \mathrm{N}$-dimethylanilines, as well as benzyl and aliphatic tertiary amines with terminal alkynes [20]. $t$-Butyl peroxide (TBP) was used as the oxidant in air at $100{ }^{\circ} \mathrm{C}$, under solvent-free conditions, with relatively long reaction times $(18-30 \mathrm{~h})$ (Scheme 11). The catalytic system was effective for aromatic, heteroaromatic and aliphatic alkynes, with the latter requiring prolonged heating. An unsymmetrical propargyldiamine could be obtained from two different amines and trimethylsilylacetylene, following a CDCdesilylation-CDC sequence. Control experiments in the absence of the alkyne supported the formation of an intermediate hemiaminal ether derived from the amine and TBP, which couples with the alkyne under the action of $\mathrm{FeCl}_{2}$.

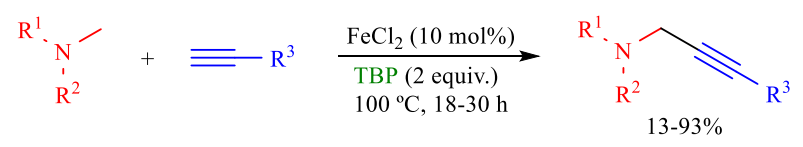

$\mathrm{R}^{1}=4-\mathrm{MeC}_{6} \mathrm{H}_{4} ; \mathrm{R}^{2}=\mathrm{Me} ; \mathrm{R}^{3}=\mathrm{Ph}, 4-\mathrm{MeC}_{6} \mathrm{H}_{4}, 4-\mathrm{MeOC}_{6} \mathrm{H}_{4}, \mathrm{PhCH}_{2} \mathrm{CH}_{2}$, 2-pyridyl, 3-pyridyl, $n$-Hex, TMS, 1-cyclohexenyl, $\mathrm{CO}_{2} \mathrm{Et}, \mathrm{Cl}\left(\mathrm{CH}_{2}\right)_{3}, \mathrm{PhOCH}_{2}$ $\mathrm{R}^{1}=\mathrm{Me} ; \mathrm{R}^{2}=\mathrm{Ph}, 2-\mathrm{MeC}_{6} \mathrm{H}_{4}, 4-\mathrm{BrC}_{6} \mathrm{H}_{4} ; \mathrm{R}^{3}=\mathrm{Ph}, 4-\mathrm{MeC}_{6} \mathrm{H}_{4}$ $\mathrm{R}^{1}=\mathrm{Me}, \mathrm{Ph} ; \mathrm{R}^{2}=\mathrm{Bn}, c$-Hept, $n$-Oct; $\mathrm{R}^{3}=\mathrm{Ph}, 3$-pyridyl

- $\ldots$

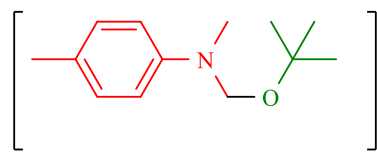

via

\section{Scheme 11}

Nakamura et al. described the redox CDC of propargylamines and terminal alkynes catalyzed by $\mathrm{ZnBr}_{2}$ in toluene at $100{ }^{\circ} \mathrm{C}$, under nitrogen for $24 \mathrm{~h} \mathrm{[21]}$. The carboncarbon triple bond of the starting propargylamine was reduced, acting as an internal oxidant. The resulting $\mathrm{N}$ tethered 1,6-enynes were produced in modest-to-good yields, in most cases using 3 equiv. of the alkyne (Scheme 12). A reaction mechanism was put forward in which alkynylzinc bromide species added to in-situ generated iminium ions by a 1,5-hydride shift.
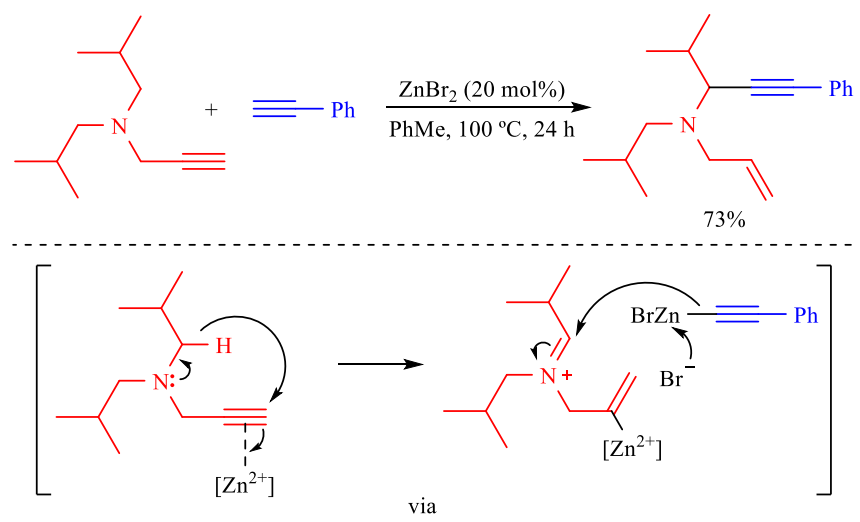

Scheme 12

The group of Mizuno also made use of $\mathrm{ZnBr}_{2}$ for the CDC of terminal alkynes and tertiary amines, in this case, in combination with a manganese oxide-based octahedral molecular sieve (OMS-2) [22]. Reactions were conducted with 2 equiv. of the tertiary amine, $5 \mathrm{~mol} \% \mathrm{ZnBr}_{2}, 100$ $\mathrm{mg} / \mathrm{mmol}$ OMS-2, in CPME at $100{ }^{\circ} \mathrm{C}$ under oxygen (1 atm) for 8-24 h (Scheme 13). Aliphatic and benzylic $N$-methyl tertiary amines were successfully coupled with aromatic alkynes; the aliphatic counterparts provided the CDC products in lower yields. The OMS-2 could be reused in four cycles with a gradual loss of activity (85-72\% yield). In the suggested reaction mechanism, alkynylzinc bromide species add to the iminium ion derived from the tertiary amine, which appears by OMS-2-promoted SET processes.

The $\alpha$-functionalization of $\alpha$-amino acids has attracted a great deal of attention in recent years [23]. Already in 2008, Li's group demonstrated that their copper-catalyzed CDC strategy developed for tertiary amines could be successfully extended to glycine amides [24]. In this case, the $\mathrm{CuBr}$ TBHP system was utilized at room temperature in $\mathrm{CH}_{2} \mathrm{Cl}_{2}$ under argon. The installation of a $N-p$-methoxyphenyl group 


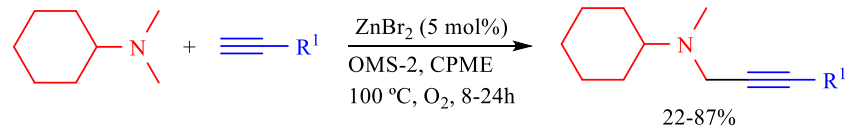

$\mathrm{R}^{1}=\mathrm{Ph}, 2-\mathrm{MeC}_{6} \mathrm{H}_{4}, 3-\mathrm{MeC}_{6} \mathrm{H}_{4}, 4-\mathrm{MeC}_{6} \mathrm{H}_{4}, 3-\mathrm{MeOC}_{6} \mathrm{H}_{4}, 4-\mathrm{FC}_{6} \mathrm{H}_{4}, 4-\mathrm{ClC}_{6} \mathrm{H}_{4}$,

4- $\mathrm{BrC}_{6} \mathrm{H}_{4}, 2-\mathrm{F}_{3} \mathrm{CC}_{6} \mathrm{H}_{4}, 1$-naphthyl, 3-pyridinyl, 3-thienyl, 1-cyclohexenyl, $\mathrm{Cl}\left(\mathrm{CH}_{2}\right)_{4}$
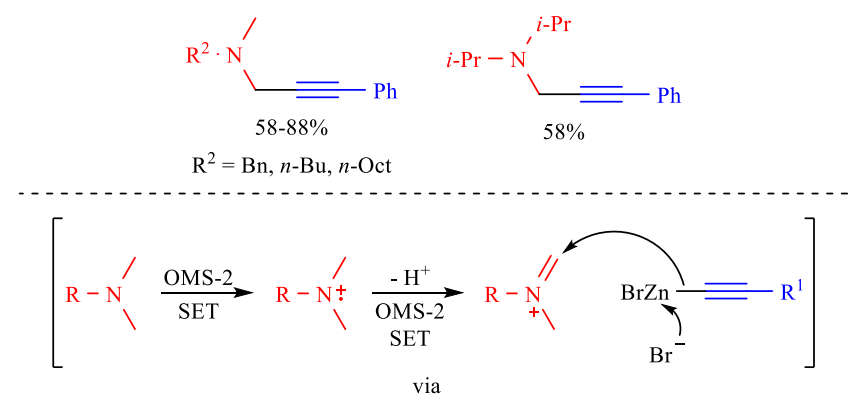

\section{Scheme 13}

(PMP) was found to be essential for the reaction to occur. Aryl alkynes were coupled with secondary and tertiary glycine amides in moderate-to-good yields (Scheme 14). Glycine esters did not react under these conditions, what allowed the selective alkynylation of a small peptide. Furthermore, a homophenylalanine derivative was synthetized by catalytic hydrogenation of the alkyne moiety of one of these compounds.

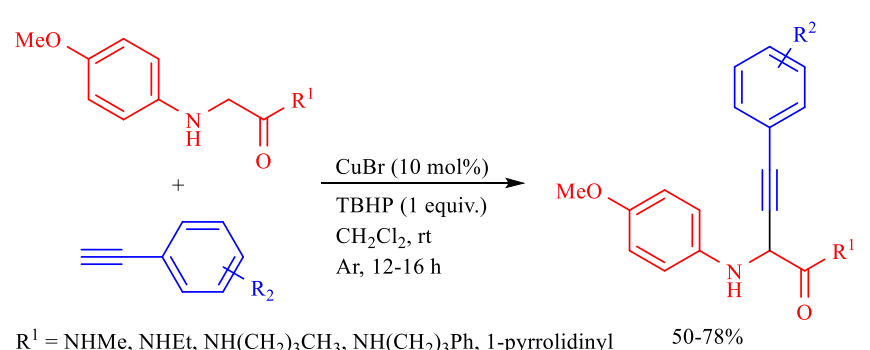

$\mathrm{R}^{1}=\mathrm{NHMe}, \mathrm{NHEt}, \mathrm{NH}\left(\mathrm{CH}_{2}\right)_{3} \mathrm{CH}_{3}, \mathrm{NH}\left(\mathrm{CH}_{2}\right)_{3} \mathrm{Ph}, 1$-pyrrolidinyl $\quad 50-78 \%$

$\mathrm{R}^{2}=\mathrm{H}, 4-\mathrm{MeC}_{6} \mathrm{H}_{4}, 4-\mathrm{PhC}_{6} \mathrm{H}_{4}, 4-\mathrm{BrC}_{6} \mathrm{H}_{4}, 2-\mathrm{MeOC}_{6} \mathrm{H}_{4}$

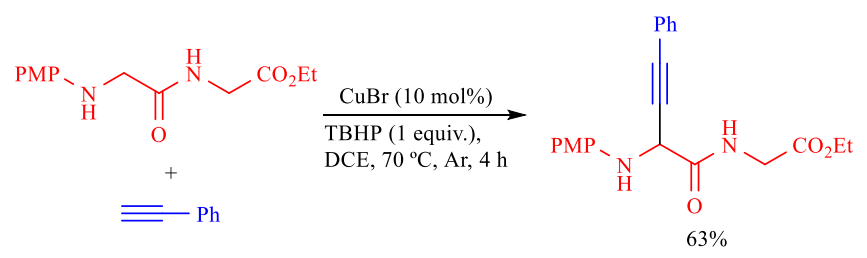

Scheme 14

It is noteworthy that, under very similar conditions but using iron instead of copper catalysis, the propargylamines derived from the coupling of the aforementioned glycine derivatives with aromatic alkynes evolved into quinolines in moderateto-good yields (Scheme 15) [25].

The tetrahydroisoquinoline (THIQ) skeleton is ranked 19th as the most recurrent nitrogen heterocycle in the FDA list of approved drugs [26]. It can be also found in natural alkaloids, such as in noscapine, which reduces tubulin polymerization without serious side effects. Waldman et al. discovered that some alkynylated THIQs exhibit equivalent or more potent antimitotic activity than noscapine [27]. $\mathrm{N}$ aryl THIQs are especially activated substrates towards CDC, that is why they have been widely studied as electrophilic partners in this reaction. Recently, Schnürch et al. studied in detail the alkynylation of THIQs through CDC [28]: $\mathrm{N}$ -

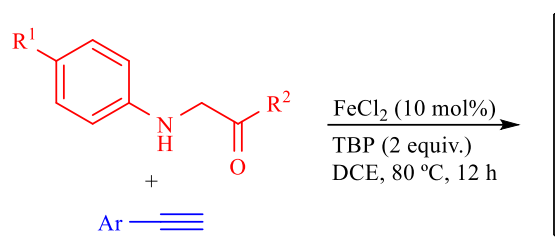<smiles>[Y17]C#CC(CC)Nc1ccc([R])cc1</smiles>

$\mathrm{R}^{1}=\mathrm{H}, \mathrm{MeO}, \mathrm{Cl}$

$\mathrm{R}^{2}=$ NHMe, OMe, OEt,<smiles>CNc1ccc2c(c1)OCO2</smiles>

$\mathrm{Ar}=\mathrm{Ph}, 4-\mathrm{YC}_{6} \mathrm{H}_{4}(\mathrm{Y}=t-\mathrm{Bu}, \mathrm{Cl}, \mathrm{OMe}, \mathrm{Ph})$<smiles>COc1ccc2cc(C)ccc2c1</smiles><smiles>[R]C(=O)c1cc([Al])c2cc([R])ccc2n1</smiles>

\section{Scheme 15}

phenyl, $N$-p-methoxyphenyl and $N$-benzyl THIQs were coupled with aromatic and aliphatic alkynes using $\mathrm{CuCl}$ and TBHP in $\mathrm{MeCN}$ at $50^{\circ} \mathrm{C}$ under argon (Scheme 16). Notably, the CDC with $N$-phenyl THIQs could be carried out faster in water and in air (4-5 bar) at the same temperature, giving the products in good-to-excellent yields.
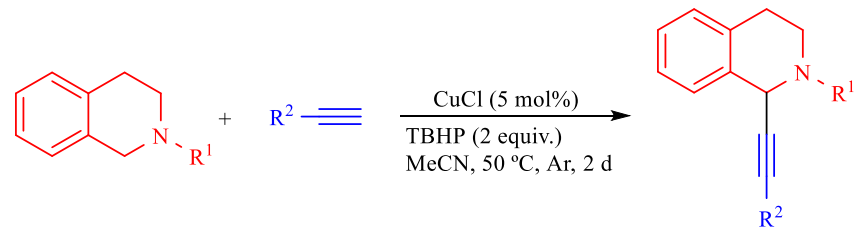

$\mathrm{R}^{1}=\mathrm{Ph}, 4-\mathrm{MeOC}_{6} \mathrm{H}_{4}, \mathrm{Bn}$

$25-93 \%$

$\mathrm{R}^{2}=\mathrm{Ph}, n$-Pent, $n$-Hex, cyclopropyl, $\left(\mathrm{CH}_{2}\right)_{4} \mathrm{C} \equiv \mathrm{CH},\left(\mathrm{CH}_{2}\right)_{3} \mathrm{Cl}$, 3-thienyl
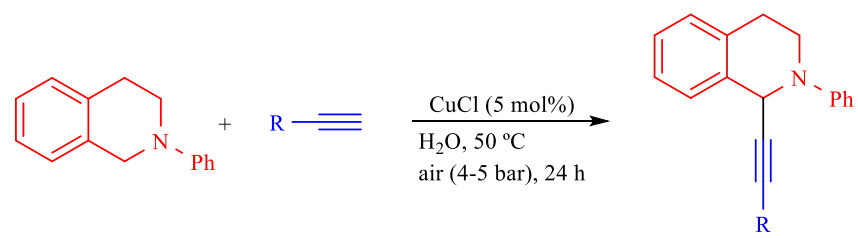

$\mathrm{R}=\mathrm{Ph}, n$-Pent, $n$-Hex, cyclopropyl, $\left(\mathrm{CH}_{2}\right)_{4} \mathrm{C} \equiv \mathrm{CH},\left(\mathrm{CH}_{2}\right)_{3} \mathrm{Cl}, 3$-thienyl $\quad 71-97 \%$

\section{Scheme 16}

In 2012, Klussmann et al. presented the first systematic and thorough study on the reaction mechanism of the CDC with THIQs (Schemes 17 and 18) [29]. Two catalytic systems were compared: $\mathrm{CuCl}_{2} \cdot 2 \mathrm{H}_{2} \mathrm{O}-\mathrm{O}_{2}$ and $\mathrm{CuBr}-\mathrm{TBHP}$. The authors concluded that, in the first case, $\mathrm{Cu}$ (II) was the real

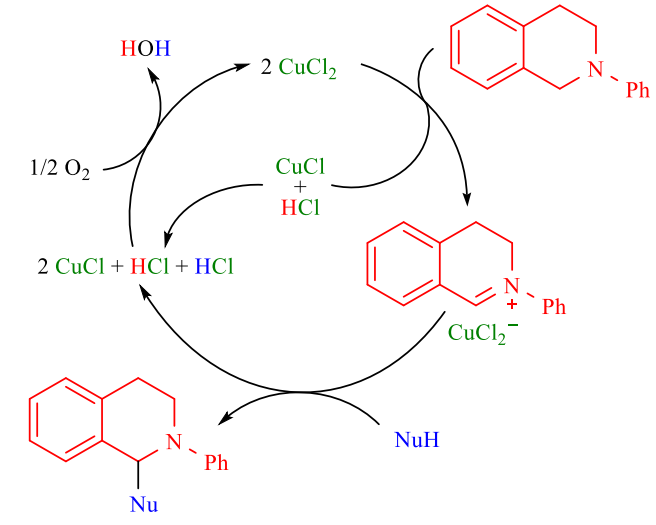

Scheme 17 
oxidant for the THIQ, whereas $\mathrm{O}_{2}$ was the terminal oxidant to reoxidize $\mathrm{Cu}(\mathrm{I})$ to $\mathrm{Cu}(\mathrm{II})$ (Scheme 17). In the second case, the iminium ion of THIQ was not detected by NMR but the $t$-butoxyperoxyl derivative instead, emerging in substantial quantities at the outset of the reaction. This derivative was postulated to be generated by a radical mechanism and to be a precursor of the iminium ion in the catalytic cycle (Scheme 18).

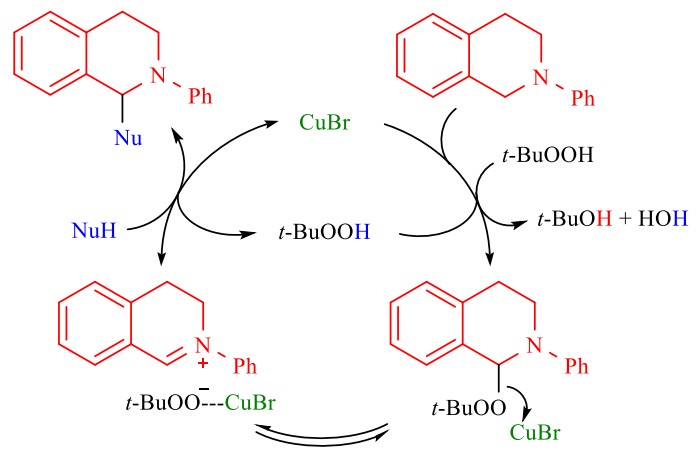

\section{Scheme 18}

The presence of an $\mathrm{N}$-aryl fragment is normally mandatory for the alkynylation of THIQs by CDC, what facilitates the proper activation of the substrate by generation of the corresponding intermediate iminium ion. In a recent study, Turner et al. combined biocatalysis and metalocatalysis to couple $N$-alkyl THIQs with terminal alkynes [30]. The enzymatic oxidation of the THIQs was accomplished with monoamine oxidase type $\mathrm{N}$ (MAO-N), whereas the creation of the $\mathrm{C}-\mathrm{C}$ bond was catalyzed by gold. Reactions were effected in one pot with 2 equiv. of the alkyne and $\mathrm{HAuCl}_{4} \cdot \mathrm{H}_{2} \mathrm{O}(5 \mathrm{~mol} \%)$ in a phosphate buffer $(\mathrm{pH} 7.8)$ at 37 ${ }^{\circ} \mathrm{C}$ in air for $16 \mathrm{~h}$ (Scheme 19). In a few cases, better yields were achieved when a one-pot two-step method was put into practice, in which the alkyne and gold catalyst were added in the second step $\left(60^{\circ} \mathrm{C}\right.$ for additional $\left.16 \mathrm{~h}\right)$. The standard protocol was applicable to $\mathrm{N}$-methyl, $\mathrm{N}$-ethyl, $\mathrm{N}$-allyl and $\mathrm{N}$ (3-butenyl) THIQs; $N$-acetyl, $N$-benzyl or $N$-unsubstituted THIQs did not give the expected products.

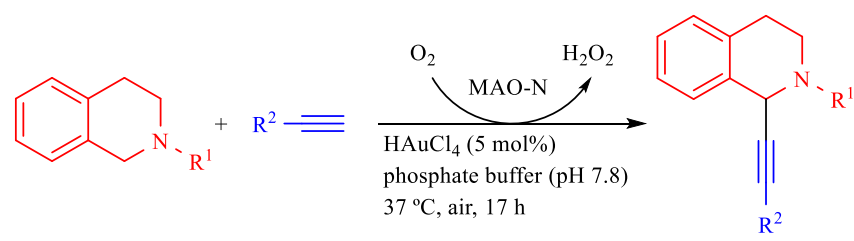

$\mathrm{R}^{1}=\mathrm{Me} ; \mathrm{R}^{2}=\mathrm{Ph}, 4-\mathrm{YC}_{6} \mathrm{H}_{4}\left(\mathrm{Y}=\mathrm{Me}, \mathrm{MeO}, n-\mathrm{Bu}, \mathrm{NEt}_{2}\right)$,

$41-88 \%$

2- $\mathrm{YC}_{6} \mathrm{H}_{4}\left(\mathrm{Y}=\mathrm{Me}, \mathrm{MeO}, \mathrm{NH}_{2}, \mathrm{~F}\right), 3-\mathrm{MeC}_{6} \mathrm{H}_{4}$, 1-naphthyl, 3-thienyl

$\mathrm{R}^{1}=\mathrm{Et}$, 2-allyl, 3-butenyl; $\mathrm{R}^{2}=\mathrm{Ph}$

Two-step method:

$\mathrm{R}^{1}=\mathrm{Me} ; \mathrm{R}^{2}=4-\mathrm{ClC}_{6} \mathrm{H}_{4}, 4-\mathrm{HC} \equiv \mathrm{CC}_{6} \mathrm{H}_{4}, 3$-pyridyl, cyclopentyl, 2-Pent

\section{Scheme 19}

\subsection{Heterogeneous catalysis}

Heterogeneous catalysis is advantageous with respect to the homogeneous counterpart in terms of sustainability (i.e., catalyst recovery and reuse), generally, minimizing the metal leaching into solution and product contamination [31]. In this sense, Che et al. prepared a SBA-15-supported iron terpyridine complex that served as catalyst in the CDC coupling of $N, N$-dimethylanilines and $N$-phenyl-1,2,3,4tetrahydroisoquinoline with arylacetylenes [32]. TBHP was deployed as an oxidant in toluene at reflux to furnish the desired propargylamines in moderate-to-good yields (Scheme 20). Catalyst recycling was studied in a related CDC reaction, showing demetalation under the same reaction conditions as above. The SBA-15-supported ligand, however, could be recovered by filtration and reutilized in five consecutive cycles, with a slight loss of activity (79$72 \%$ yield), upon the addition of $\mathrm{Fe}\left(\mathrm{ClO}_{4}\right)_{2} \cdot 6 \mathrm{H}_{2} \mathrm{O}$ and in situ regeneration of the complex.

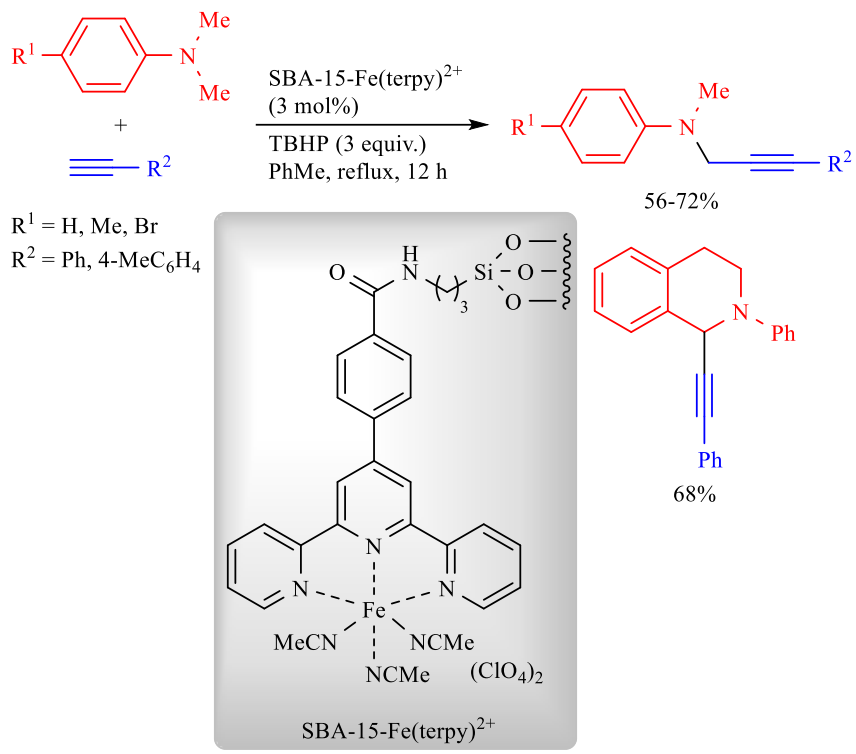

\section{Scheme 20}

In 2013, Li and Moores et al. compared the catalytic activity of magnetite nanoparticles $\left(\mathrm{Fe}_{3} \mathrm{O}_{4}\right)$ with that of copper ferrite nanoparticles $\left(\mathrm{CuFe}_{2} \mathrm{O}_{4}\right)$ in $\mathrm{CDC}$ reactions; only copper ferrite was found to catalyze the CDC of THIQs with arylacetylenes [33]. Reactions were carried out using 10 $\mathrm{mol} \% \mathrm{CuFe}_{2} \mathrm{O}_{4}$ and 2,3-dichloro-5,6-dicyano-1,4benzoquinone (DDQ, 1 equiv.) in decane at $100{ }^{\circ} \mathrm{C}$ for $24 \mathrm{~h}$ (Scheme 21). The CDC of other tertiary amines or aliphatic terminal alkynes was not explored. The catalyst could be efficiently recovered magnetically and reutilized in ten cycles with no apparent loss of activity. A heterogeneous reaction mechanism was suggested based on the low leaching measured $(0.39 \mathrm{ppm})$ in the supernatant and the invariable size and morphology of the nanoparticles upon reuse. A reaction mechanism was set forth in which the alkyne is activated by ferrite lattice $\mathrm{Cu}$, while a neighboring $\mathrm{Cu}$ or $\mathrm{Fe}$ atom could coordinate the THIQ iminium ion, followed by coupling of these two moieties.

In 2014, Truong and Phan et al. made an important contribution to the heterogeneous synthesis of propargylamines through CDC reactions. They first exploited the copper-based metal-organic framework MOF199 for the CDC of $N, N$-dimethylanilines (2 equiv.) with aromatic and aliphatic alkynes [34]. The optimized conditions involved 5 mol\% MOF-199 and TBHP in dimethylacetamide (DMA) at $120^{\circ} \mathrm{C}$ for 150 min under $\mathrm{Ar}$ (Scheme 22). The catalyst was recovered by filtration and subjected to washing with abundant amounts of DMF and $\mathrm{EtOH}$, and to drying at $170{ }^{\circ} \mathrm{C}$ under vacuum for $6 \mathrm{~h}$ prior to reutilization. In this way, the catalyst could be reused in ten consecutive cycles with near quantitative conversion and no appreciable loss of crystallinity. 


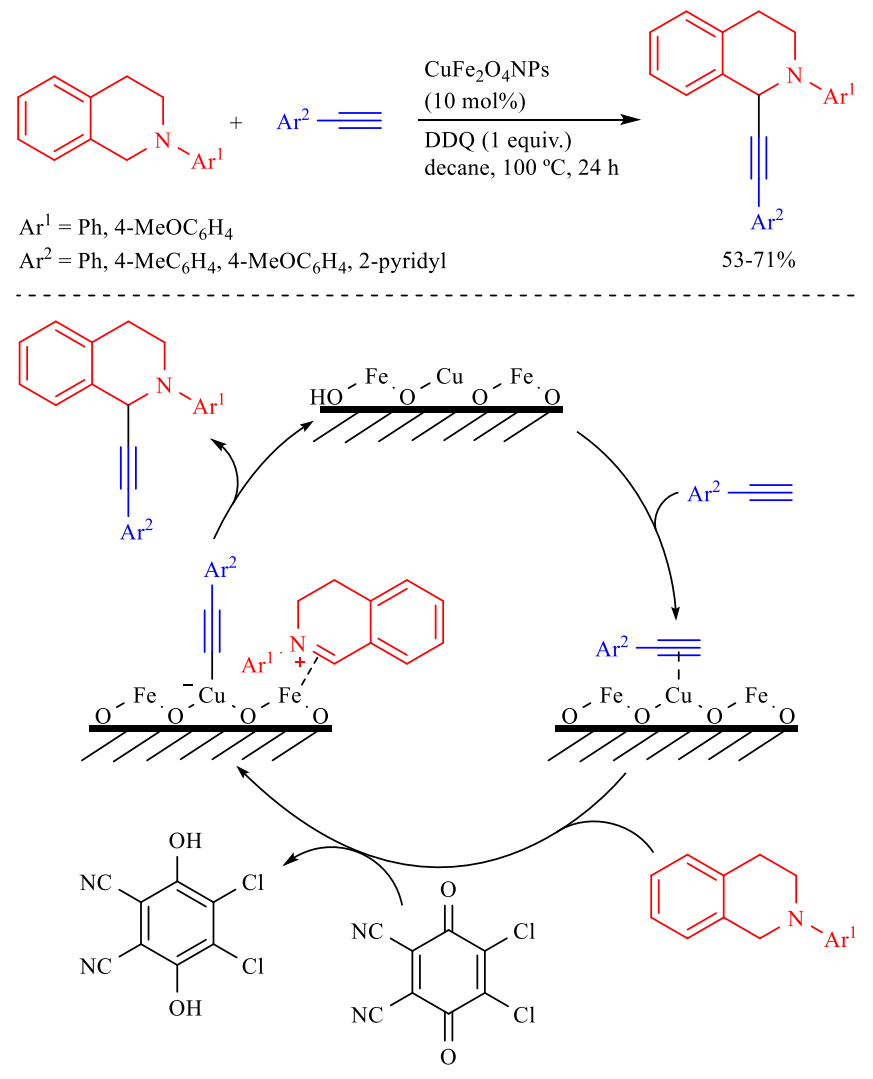

Scheme 21

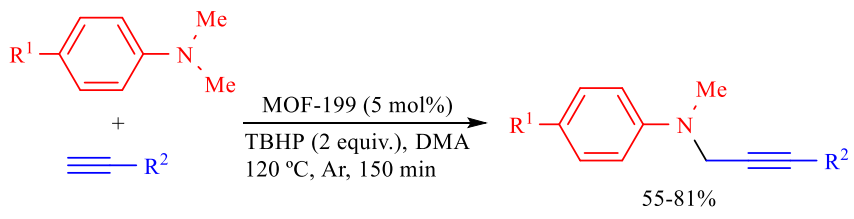

$\mathrm{R}^{1}=\mathrm{H}, \mathrm{Me}, \mathrm{Br}$

$\mathrm{R}^{2}=\mathrm{Ph}, 4-\mathrm{MeC}_{6} \mathrm{H}_{4}, 4-\mathrm{MeOC}_{6} \mathrm{H}_{4}, n-\mathrm{Hex}$

\section{Scheme 22}

Under analogous reaction conditions as above, but using MOF $\mathrm{Cu}_{2}(\mathrm{BDC})_{2}(\mathrm{DABCO})_{2}$ (5 $\mathrm{mol} \%$ ), the same group described the conversion of $N$-methylanilines (2 equiv.) into $\mathrm{N}$-aryl- $\mathrm{N}$-methylpropargylamines [35] (Scheme 23). TBHP was used as an oxidant and methylating agent in dimethylacetamide (DMA) at $120^{\circ} \mathrm{C}$. The process could be scaled up to $20 \mathrm{mmol}$. The catalyst was isolated by filtration, washed with large amounts of DMF, dried at $140^{\circ} \mathrm{C}$ under vacuum $(6 \mathrm{~h})$ and recycled in ten runs maintaining a high performance with negligible leaching. Copper salts such as $\mathrm{Cu}\left(\mathrm{NO}_{3}\right)_{2}$ and $\mathrm{Cu}(\mathrm{OAc})_{2}$ showed comparable catalytic activity to that of the MOF.

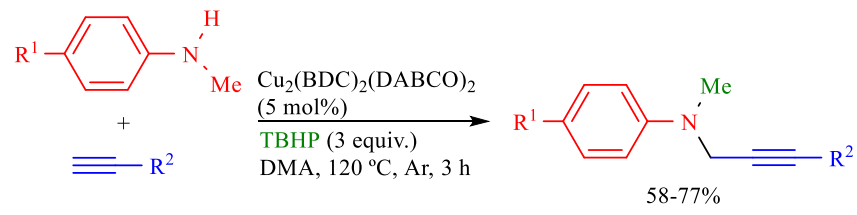

$\mathrm{R}^{1}=\mathrm{H}, \mathrm{MeO}, \mathrm{Cl}$

$\mathrm{R}^{2}=\mathrm{Ph}, 4-\mathrm{MeC}_{6} \mathrm{H}_{4}, 4-\mathrm{MeOC}_{6} \mathrm{H}_{4}, n-\mathrm{Hex}$

Scheme 23

Scheme 23
The same type of transformation was reported under the catalysis of superparamagnetic $\mathrm{CuFe}_{2} \mathrm{O}_{4}$ nanoparticles [36] (Scheme 24). The catalyst was recovered by magnetic separation and recycled (after washing and drying) in six runs with constant conversion, unchanged crystallinity and negative leaching test ( $30 \mathrm{ppm}$ in the filtrate). It must be mentioned that 3 equiv. of the $N$-methylaniline are required with respect to the alkyne in an Ar atmosphere. TBHP was considered the source of $\mathrm{Me}$ radical, after previous $\mathrm{Cu}$ promoted decomposition into $t$-butoxyl radical and further evolution of the latter. Reaction of Me radical with $N$ methylaniline would lead to $N, N$-dimethylaniline, which would undergo the standard CDC pathway.

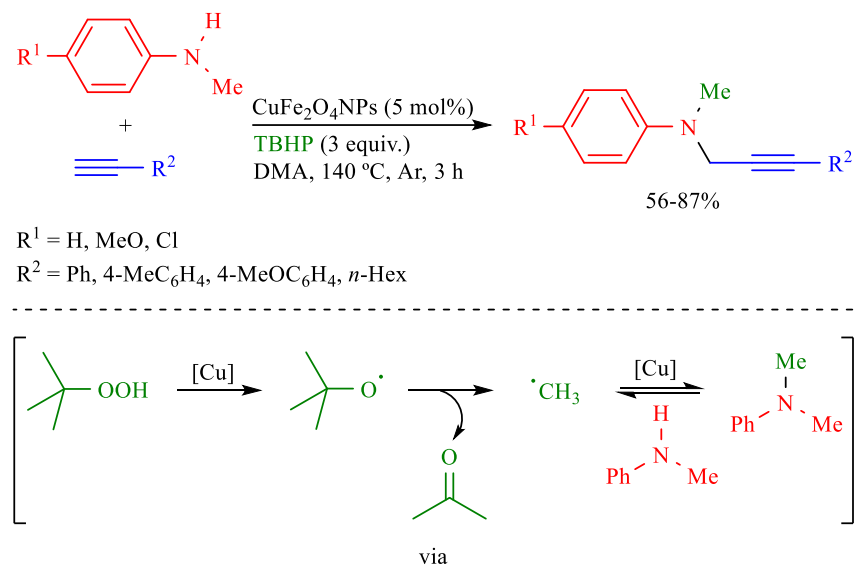

\section{Scheme 24}

Alonso et al. presented a new heterogeneous catalyst for the CDC of tertiary amines and terminal alkynes comprised of oxidized copper nanoparticles on sodium Y zeolite [37]. The catalyst, in the presence of aqueous TBHP, was applied at $1.5 \mathrm{~mol} \%$ loading to make an array of propargylamines in moderate-to-excellent yields (Scheme 25). Contrary to other previously reported methodologies, it was demonstrated that the copper-catalyzed CDC could be conducted under solvent-free conditions and without the requirement of an inert atmosphere. The reaction conditions were compatible with the presence of different functionalities such as methoxy, ester, cyano, hydroxy, halogen and ketone. Not only activated $N, N$-dimethylanilines were covered in this study but benzyl and aliphatic amines. The catalyst was successfully both reutilized in seven successive runs and adapted to a $12 \mathrm{mmol}$ scale. Moreover, its catalytic activity surpassed that of various commercially available copper catalysts, depleting the formation of 1,3-diynes as byproducts. The propounded reaction pathway discloses the pivotal role of free radicals (methyl radical, in particular) and that of the $\mathrm{Cu}(\mathrm{I}) / \mathrm{Cu}(\mathrm{II})$ redox couple (Scheme 25). In addition, the methylation-alkynylation of the secondary amine $N$-methylaniline took place quantitatively, under the same conditions, to furnish the expected tertiary propargylamine. The results of this study also highlight the utility of nanosized copper in catalysis when compared with bulk copper sources. 


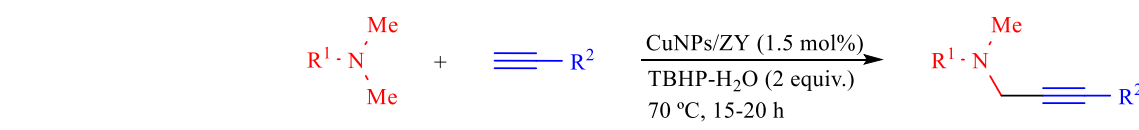

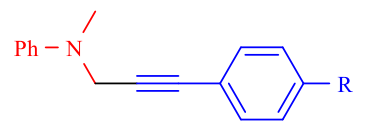

$\mathrm{R}=\mathrm{H}, \mathrm{Me}, \mathrm{OMe}, \mathrm{CO}_{2} \mathrm{Me}$

$73-98 \%$

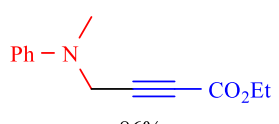

$86 \%$

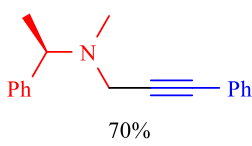

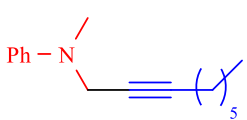

$80 \%$

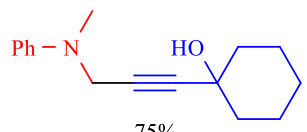

$75 \%$

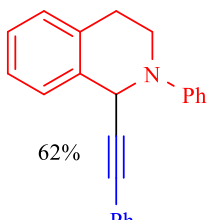

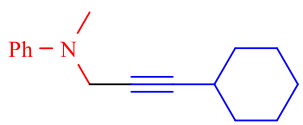

$95 \%$

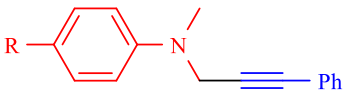

$\mathrm{R}=\mathrm{Me}, \mathrm{Br}, \mathrm{CO}_{2} \mathrm{Et}, \mathrm{CN}$ $43-90 \%$

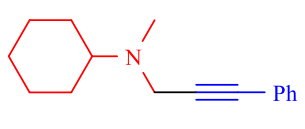

$95 \%$

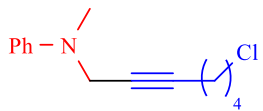

$93 \%$
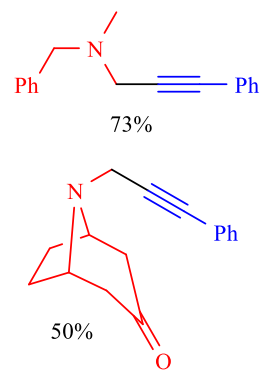

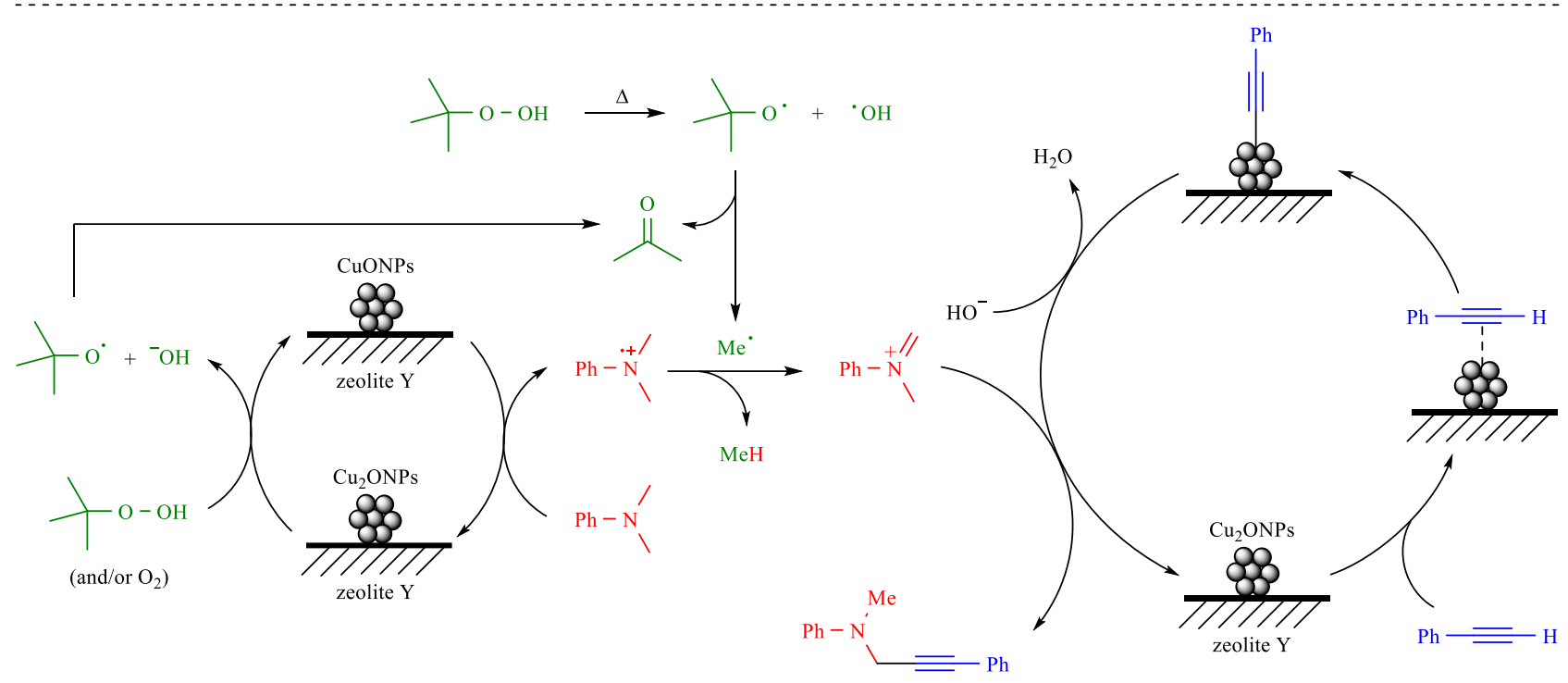

Scheme 25

Singh and Jain et al. prepared $\mathrm{Cu}_{6} \mathrm{Se}_{4.5} \mathrm{NPs}$ from $\mathrm{CuSePh}$ and applied them to the CDC of $\mathrm{N}, \mathrm{N}$-dimethylbenzylamines and $N, N$-dimethylanilines with terminal alkynes [38]. Reactions occurred in the presence of TBHP under nitrogen, with the latter preventing the oxidation of the benzylic amines to benzaldehydes. In general, lower yields were attained when the aryl moieties were substituted with electron-withdrawing groups as well as for aliphatic and heterocyclic alkynes (Scheme 26). The catalyst was reused in four cycles with a decrease in the yield that was attributed to partial agglomeration of the nanoparticles and some leaching of the catalyst. An analogous reaction mechanism to those previously published with TBHP as the oxidant was invoked.

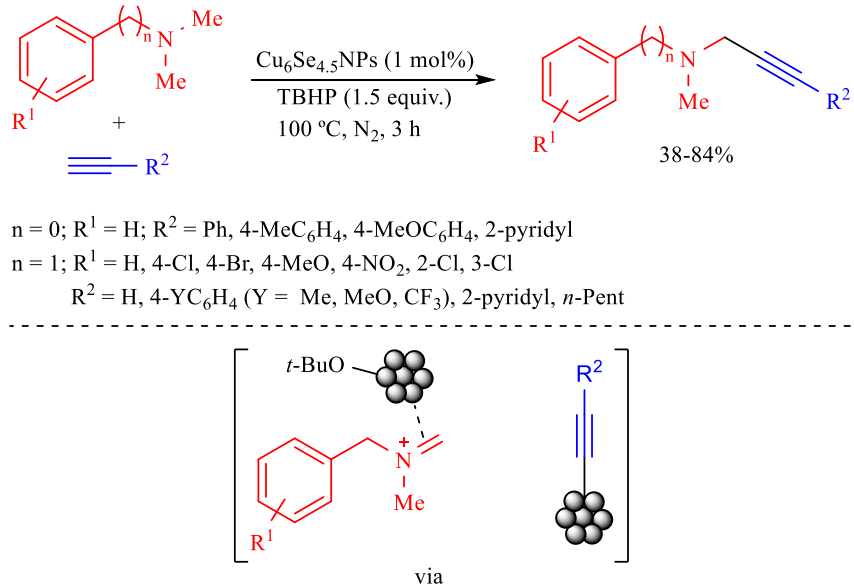

Scheme 26

(C) 2014 Bentham Science Publishers 
More recently, Gómez and Favier et al. disclosed the first application of zero-valent CuNPs to the synthesis of propargylamines through CDC [39]. The $\mathrm{Cu}(0) \mathrm{NPs}(1.7-2.4$ nm) were prepared by reduction of $\mathrm{Cu}(\mathrm{I})$ and $\mathrm{Cu}(\mathrm{II})$ precursors in glycerol, in the presence of PVP as stabilizer under $\mathrm{H}_{2} . N, N$-Dimethylanilines, $N, N$-dimethylbenzylamine and $N$-methylaniline were subjected to CDC with both aromatic and aliphatic alkynes; 2 equiv. of the amine and TBHP were used in glycerol at $100{ }^{\circ} \mathrm{C}$ for $2 \mathrm{~h}$ (Scheme 27). Due to the relatively narrow substrate scope studied, it is difficult to assess the functional group compatibility of this catalytic system. Reusability of the catalyst was not tested in this particular reaction but was found to be effective in the amination of iodobenzene, included in the same publication.

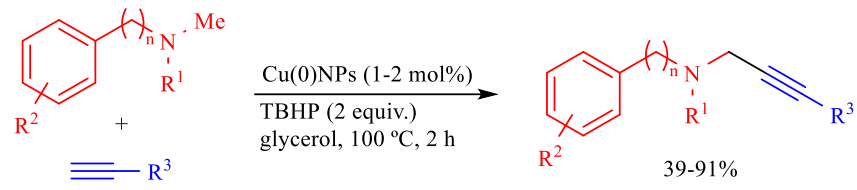

$\mathrm{n}=0 ; \mathrm{R}^{1}=\mathrm{H} ; \mathrm{R}^{2}=\mathrm{H} ; \mathrm{R}^{3}=\mathrm{Ph}, 4-\mathrm{MeC}_{6} \mathrm{H}_{4}, n$-Pent

$\mathrm{n}=0 ; \mathrm{R}^{1}=\mathrm{Me} ; \mathrm{R}^{2}=\mathrm{H}, 4-\mathrm{Br}, 3-\mathrm{Me} ; \mathrm{R}^{3}=\mathrm{Ph}, 4-\mathrm{MeC}_{6} \mathrm{H}_{4}, 4-\mathrm{MeO}_{2} \mathrm{CC}_{6} \mathrm{H}_{4}, n$-Pent

$\mathrm{n}=1 ; \mathrm{R}^{1}=\mathrm{Me} ; \mathrm{R}^{2}=\mathrm{H} ; \mathrm{R}^{3}=\mathrm{Ph}$

\section{Scheme 27}

\section{PHOTOREDOX CATALYSIS}

In recent years, photoredox catalysis has gained considerable interest as a sustainable and green synthetic tool, making use of low-energy renewable light sources to promote organic transformations [40]. In 2012, the groups of Stephenson and Rueping pioneered the synthesis of propargylamines by CDC with a dual catalytic system consisting of a photoredox catalyst and a metal catalyst. Stephenson et al. alkynylated THIQs using the photoactive metal complex $\mathrm{Ru}(\mathrm{bpy})_{3} \mathrm{Cl}_{2}$ (1 mol\%) in combination with $\mathrm{BrCCl}_{3}$ as the oxidant, under the action of blue LEDs in DMF for $3 \mathrm{~h}$, and subsequent addition of the alkyne, $\mathrm{CuBr}(15 \mathrm{~mol} \%)$ and $\mathrm{Et}_{3} \mathrm{~N}$ in the absence of light (Scheme 28) [41]. The success of this reaction is undebatable but this approach cannot be considered green and sustainable because of the large amount of reagents deployed $\left[\mathrm{BrCCl}_{3}\right.$ (3 equiv.), $\mathrm{Et}_{3} \mathrm{~N}$ (5 equiv.) and alkyne (5 equiv.)]. In addition, the procedure was not straightforward and required control of the THIQ oxidation prior to the $\mathrm{C}-\mathrm{C}$ bond forming step under an argon atmosphere. The reaction was largely accelerated by carrying out the experiment in a continuous-flow photoreactor [42]: the $3 \mathrm{~h}$ batch reaction time for the THIQ iminium formation was reduced to a residence time of only $0.5 \mathrm{~min}$ when the reaction was performed in flow.

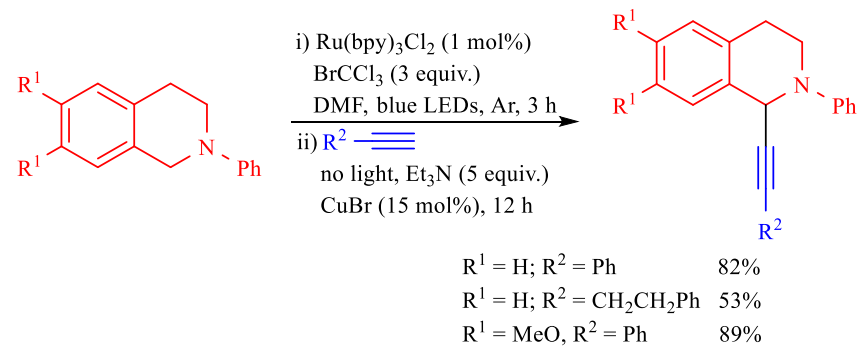

\section{Scheme 28}

In parallel to the aforementioned work, Rueping et al. thoroughly studied the CDC of N-substituted THIQs and terminal alkynes utilizing $\left[\mathrm{Ru}(\mathrm{bpy})_{2}(\mathrm{dtbbpy})\right]\left(\mathrm{PF}_{6}\right)_{2}$ as photocatalyst and $(\mathrm{MeCN})_{4} \mathrm{CuPF}_{6}$ as the metal catalyst under the radiation of a $5 \mathrm{~W}$ fluorescent bulb [43]. A wide range of $\mathrm{N}$-aryl THIQs was alkynylated in moderate-to-excellent yields (50-95\%) with aromatic and aliphatic alkynes, as well as with triphenylsilylacetylene (Scheme 29). Furthermore, the procedure was not restricted to $N$-aryl THIQs but it was equally effective for THIQ-derived glycine esters (43-73\%). In both cases, an excess of the alkyne (5 equiv.) was employed. The authors noted that $\operatorname{Ag}\left(\mathrm{O}_{2} \mathrm{CCF}_{3}\right)$ was an alternative salt to $(\mathrm{MeCN})_{4} \mathrm{CuPF}_{6}$ in cases where the latter was less effective. Two catalytic cycles were proposed to participate in the reaction mechanism. On one hand, the photoredox cycle activates the amine, with the intervention of the Ru complex, to form the amine radical cation and the iminium ion with reoxidation of the photocatalyst by $\mathrm{O}_{2}$. The transmutation of the amine radical cation into the iminium ion might occur by abstraction of $\mathrm{H}^{*}$ by the superoxide anion or by deprotonation by the amine or superoxide radical anion, with the concomitant electron transfer to $\mathrm{Ru}(\mathrm{II})$, $\mathrm{Ru}(\mathrm{II})^{*}$ or HOO . On the other hand, the $\mathrm{Cu}$ acetylide is formed in the metal catalytic cycle to, ultimately, add to the iminium ion and give the propargylamine.
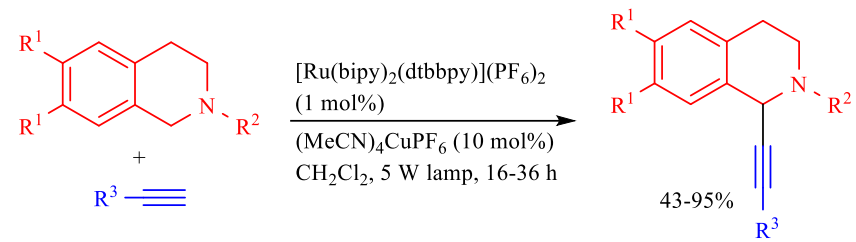

$\mathrm{R}^{1}=\mathrm{H} ; \mathrm{R}^{2}=\mathrm{Ph}, 4-\mathrm{YC}_{6} \mathrm{H}_{4}(\mathrm{Y}=\mathrm{Me}, \mathrm{Et}, \mathrm{Cl}), 2-\mathrm{MeC}_{6} \mathrm{H}_{4}$, 2-naphthyl;

$\mathrm{R}^{3}=\mathrm{Ph}, 4-\mathrm{YC}_{6} \mathrm{H}_{4}(\mathrm{Y}=\mathrm{Me}, t$-Bu, $n$-Pent $), 6-\mathrm{MeO}$-2-naphthyl, cyclopropyl, cyclohexyl, $n-\mathrm{Bu}, \mathrm{Ph}_{3} \mathrm{Si}, \mathrm{CO}_{2} \mathrm{Et}$

$\mathrm{R}^{1}=\mathrm{MeO} ; \mathrm{R}^{2}=\mathrm{Ph} ; \mathrm{R}^{3}=\mathrm{Ph}$

$\mathrm{R}^{1}=\mathrm{H}, \mathrm{MeO} ; \mathrm{R}^{2}=\mathrm{CH}_{2} \mathrm{CO}_{2} \mathrm{Me}, \mathrm{CH}_{2} \mathrm{CO}_{2}(t-\mathrm{Bu}) ; \mathrm{R}^{3}=\mathrm{Ph}, 4-\mathrm{MeC}_{6} \mathrm{H}_{4}, 4-(t-\mathrm{Bu}) \mathrm{C}_{6} \mathrm{H}_{4}$, 1-cyclohexenyl

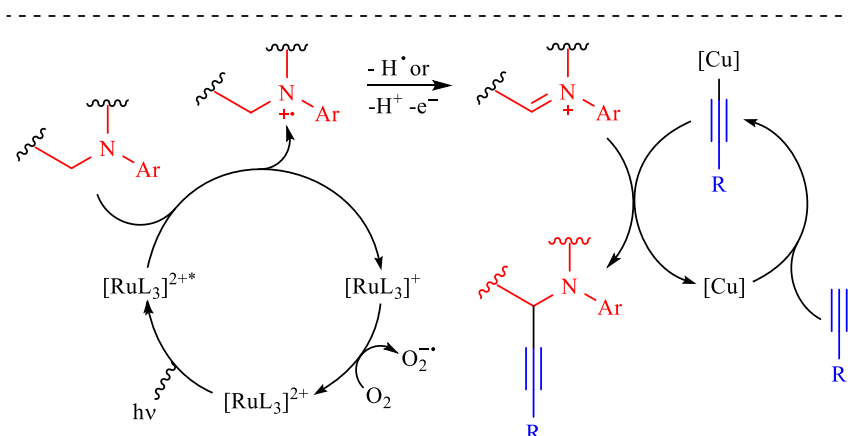

Scheme 29

\section{ASYMMETRIC SYNTHESIS}

The alkynylation involving one of the two enantiotopic hydrogens of $\mathrm{CH}_{2} \mathrm{~N}$ in substrates such as THIQs and glycine derivatives leads to chiral propargylamines. That is why different research groups have attempted the asymmetric alkynylation of THIQs through CDC, primarily, under copper catalysis [44]. The copper-catalyzed enantioselective CDC of THIQs and terminal alkynes was pioneered by the group of Li [45]. CuOTf in the presence of TBHP and Pybox ligand promoted this coupling in moderate yields and up to $74 \%$ e.e. (Scheme 30). The THIQ was used in two-fold excess, with the conditions including prolonged heating $(2 \mathrm{~d})$ under a nitrogen atmosphere. In general, the yield (11-65\%) and e.e. (30\%) recorded were lower for aliphatic alkynes. 


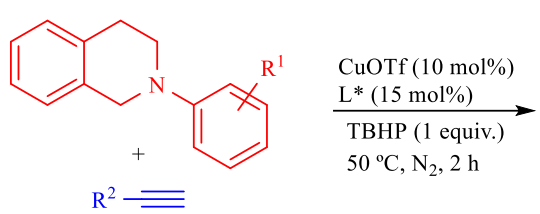

$\mathrm{R}^{1}=\mathrm{H}, 4-\mathrm{MeO}, 2-\mathrm{MeO}$

$\mathrm{R}^{2}=\mathrm{Ph}, 4-\mathrm{MeOC}_{6} \mathrm{H}_{4}, 4-\mathrm{BrC}_{6} \mathrm{H}_{4}, n$-Hex, TMS, 2-pyridyl

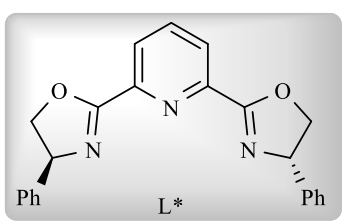

\section{Scheme 30}

In 2013, Su et al. described the asymmetric CDC of THIQs and terminal alkynes under solvent-free high-speed ballmilling conditions [46]. Pybox was the optimized chiral ligand, which in the presence of DDQ, silica gel and two copper steel balls led to the corresponding enantiomerically enriched propargylamines in up to $77 \%$ yield and $79 \%$ e.e. (Scheme 31). The substituent on the $\mathrm{N}$ atom of the THIQs did not have any significant influence in the enantioselectivity, whereas the latter was rather low in the case of using aliphatic alkynes. Some of the yields could be enhanced by the addition of $5 \mathrm{~mol} \% \mathrm{Cu}(\mathrm{OTf})_{2}$, albeit the e.e.'s still were low (20-22\% e.e.). The method was extended to a $10 \mathrm{mmol}$ scale in reasonably good yield (69\%) and e.e. (70\%). What is more, the copper balls, acting as catalyst and milling balls, could be easily recovered from the reaction medium, though no studies on the nature of the catalysis and potential degradation of the balls were undertaken.

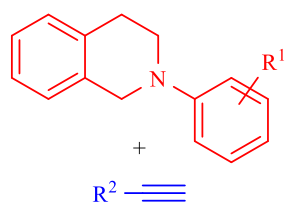

$\mathrm{R}^{1}=\mathrm{H}, 4-\mathrm{Me}, 4-\mathrm{MeO}, 2-\mathrm{MeO}$ $\mathrm{R}^{2}=\mathrm{Ph}, 4-\mathrm{MeC}_{6} \mathrm{H}_{4}, 4-\mathrm{FC}_{6} \mathrm{H}_{4}, \mathrm{CO}_{2} \mathrm{Me}, \mathrm{CO}_{2} \mathrm{Et}$, 2-pyridyl, $n$ - $\mathrm{Pr}$

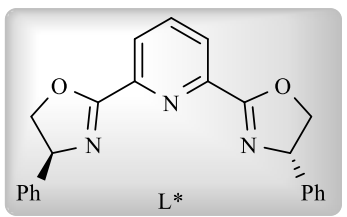

\section{Scheme 31}

Liu et al. managed to augment the e.e.'s of the THIQ alkynylation by changing the typical aryl group on the $\mathrm{N}$ atom into the $\mathrm{Cbz}$ group [47]. A rather complex catalytic system had to be developed, including: $\mathrm{Ph}_{3} \mathrm{CBF}_{4}$, a Pyboxtype ligand, $\mathrm{CuBr}, \mathrm{EtOH}, \mathrm{Yb}(\mathrm{OTf})_{3}, \mathrm{KOH}$ and $\mathrm{H}_{2} \mathrm{O}$ in a $\mathrm{CH}_{2} \mathrm{Cl}_{2}-\mathrm{PhMe}$ solvent mixture. High enantioselectivities were reached for aromatic alkynes at room temperature though, once more, low yield and e.e. were noted for aliphatic alkynes (Scheme 32). The reactions were relatively slow $(48 \mathrm{~h})$ and required 2 equiv. of the alkyne. The authors postulated the concurrence of two hemiaminals in the process, though the role of water was not clarified. It must be remarked that the procedure was successfully implemented for the synthesis of homoprotoberberine and an intermediate in the synthesis of emetine.

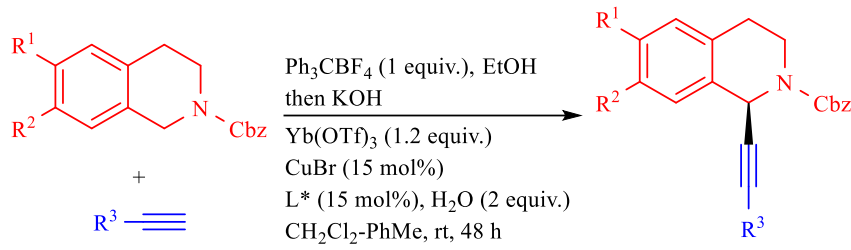

$\mathrm{R}^{1}=\mathrm{H} ; \mathrm{R}^{2}=\mathrm{Me}, \mathrm{Br}, \mathrm{Cl} ; \mathrm{R}^{3}=\mathrm{Ph}$

$15-70 \%$ yield

$30-95 \%$ e.e.

$\mathrm{R}^{1}=\mathrm{R}^{2}=\mathrm{MeO}$ or $\mathrm{R}^{1}-\mathrm{R}^{2}=\mathrm{OCH}_{2} \mathrm{O} ; \mathrm{R}^{3}=\mathrm{Ph}$

$\mathrm{R}^{1}=\mathrm{R}^{2}=\mathrm{H} ; \mathrm{R}^{3}=\mathrm{Ph}, 4-\mathrm{YC}_{6} \mathrm{H}_{4}\left(\mathrm{Y}=\mathrm{Me}, \mathrm{CF}_{3}, \mathrm{~F}, \mathrm{Cl}, \mathrm{Br}, \mathrm{MeO}, \mathrm{Ph}\right), 3,4-(\mathrm{MeO})_{2} \mathrm{C}_{6} \mathrm{H}_{3}$,

$3-\mathrm{YC}_{6} \mathrm{H}_{4}(\mathrm{Y}=\mathrm{Me}, \mathrm{F}, \mathrm{Cl}, \mathrm{MeO}), n$-Hex, $\mathrm{CO}_{2} \mathrm{Et}$, 2-thienyl, $\beta$-styryl,

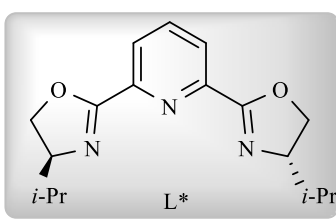<smiles>[Tl]c1ccc2c(c1)OCO2</smiles>

\section{Scheme 32}

In 2015, Li's group combined photoredox catalysis with a chiral copper complex to substantially increase both, the yield and enantioselectivity previously reported under only copper catalysis (Scheme 33) [48]. Very mild conditions were practiced in the presence of an Ir complex as photocatalyst, $\mathrm{CuBr}$, a bynaphthyl-type chiral ligand and $(\mathrm{BzO})_{2}$, under visible light irradiation (Scheme 33). It must be highlighted that, for the first time, the e.e.'s of the CDC products derived from aliphatic alkynes were high (up to $90 \%$ e.e.), though the yields were low-to-moderate (20$57 \%$ ). The reaction mechanism put forward contains two

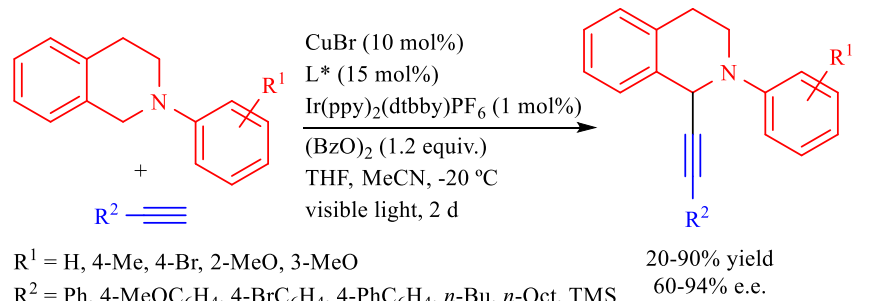

$\mathrm{R}^{2}=\mathrm{Ph}, 4-\mathrm{MeOC}_{6} \mathrm{H}_{4}, 4-\mathrm{BrC}_{6} \mathrm{H}_{4}, 4-\mathrm{PhC}_{6} \mathrm{H}_{4}, n$-Bu, $n$-Oct, TMS $\quad 60-94 \%$ e.e.
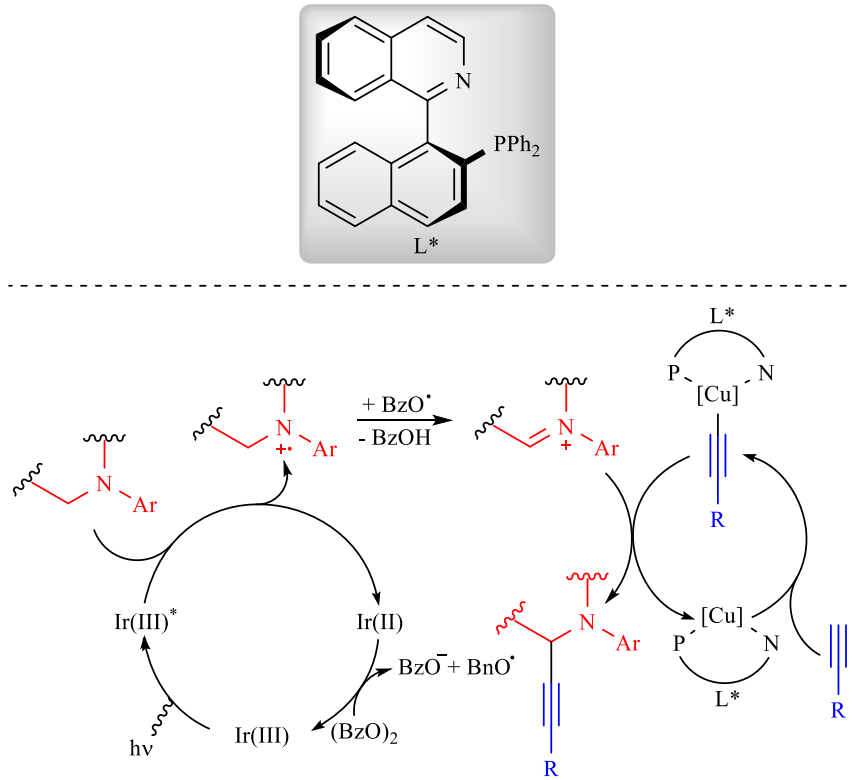

Scheme 33 
catalytic cycles resembling those depicted in Scheme 29 but, in which, $\operatorname{Ir}(\mathrm{II})$ is reoxidized to $\operatorname{Ir}(\mathrm{III})$ by the SET reduction of $(\mathrm{BzO})_{2}$ to $\mathrm{BzO}^{-}$anion and $\mathrm{BzO}$. radical.

Khan et al. also made use of dual catalysis (i.e., photoredox and transition-metal catalysis) for the enantioselective CDC of THIQs and terminal alkynes [49]. In this case, a $\mathrm{Cu}(\mathrm{I})$ complex with a $C_{2}$-symmetric iminoalcohol-based ligand was combined with Rose Bengal as photoredox catalyst under visible light and with molecular oxygen as the terminal oxidant. The chiral propargylamines were obtained in moderate-to-good yields and excellent enantioselectivities, even for the more problematic alkynes, such as trimethylsilylacetylene, alkyl- and cycloalkyl-substituted alkynes (Scheme 34). In the reaction mechanism, excited Rose Bengal was considered to oxidize the THIQ to the corresponding radical cation, with the former going back to the ground state by the action of molecular oxygen. Hydrogen abstraction of the mentioned radical cation by superoxide radical anion would generate the iminium ion of the THIQ, that would enter the copper cycle similarly to as stated by others.
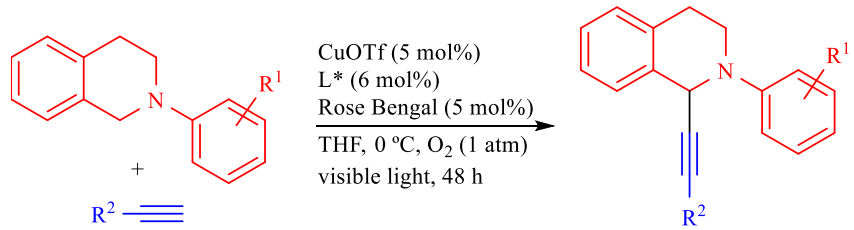

$50-90 \%$ yield

$\mathrm{R}^{1}=\mathrm{H}, 4-\mathrm{Me}, 4-\mathrm{Cl}, 4-\mathrm{MeO}, 2-\mathrm{MeO}$ $30-99 \%$ e.e.

$\mathrm{R}^{2}=\mathrm{Ph}, 4-\mathrm{MeOC}_{6} \mathrm{H}_{4}, 4-\mathrm{BrC}_{6} \mathrm{H}_{4}, 4-\mathrm{FC}_{6} \mathrm{H}_{4}, 3-\mathrm{ClC}_{6} \mathrm{H}_{4}, c$-Pr, $n$-Oct, TMS
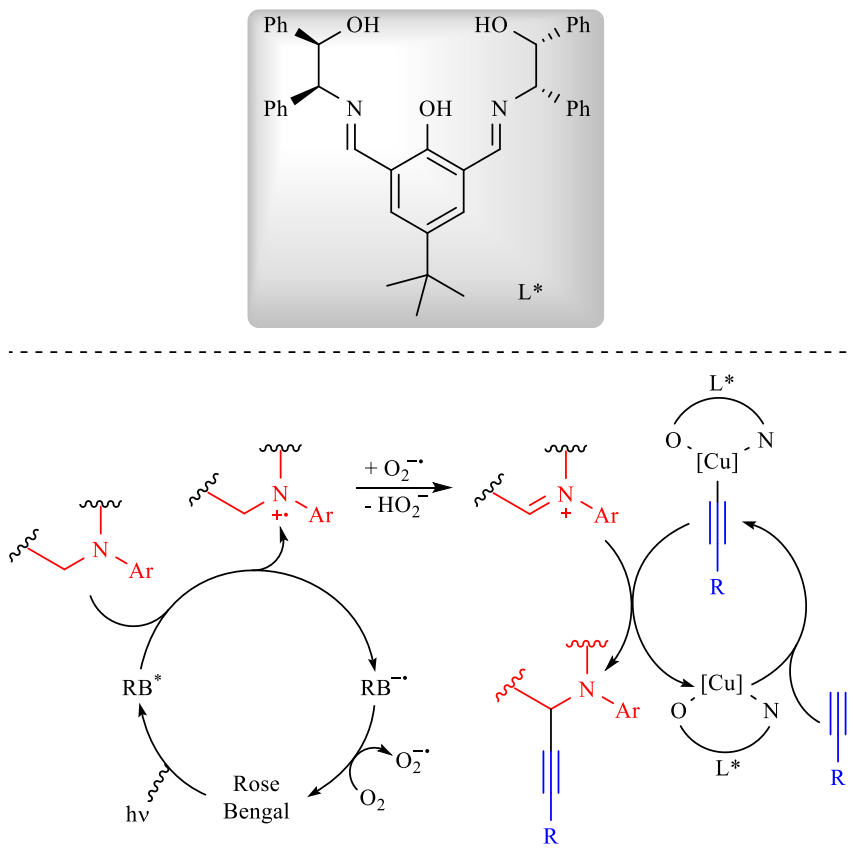

Scheme 34

Recently, Feng et al. introduced a chiral $N, N$ '-oxide ligand, together with a $\mathrm{Zn}$ (II)-Fe(II) bimetallic cooperative catalytic system, for the asymmetric alkynylation of $N$-PMPsubstituted THIQs under a molecular oxygen atmosphere and mild conditions [50]. The presence of both, $5 \AA$ molecular sieves $\mathrm{NaB}\left[3,5-\left(\mathrm{F}_{3} \mathrm{C}\right)_{2} \mathrm{C}_{6} \mathrm{H}_{3}\right]_{4}$ was found to be crucial to attain higher yields and e.e.'s. Aromatic alkynes led to moderate-to-good yields of the CDC products and excellent enantioselectivities; aliphatic alkynes, however, gave the products with poor-to-moderate enantioselectivities (Scheme 35). Differently substituted THIQs on the $\mathrm{N}$ atom and on the aromatic ring were also explored, in general, with good results. The process could be successfully scaled to a gram production (70\% yield, $93 \%$ e.e.). Mechanistic studies seem to support the cooperation of Fe(II) and oxygen in the oxidation of the THIQ and the assistance of $\mathrm{Zn}(\mathrm{II})$ in the formation of the metal acetylide.
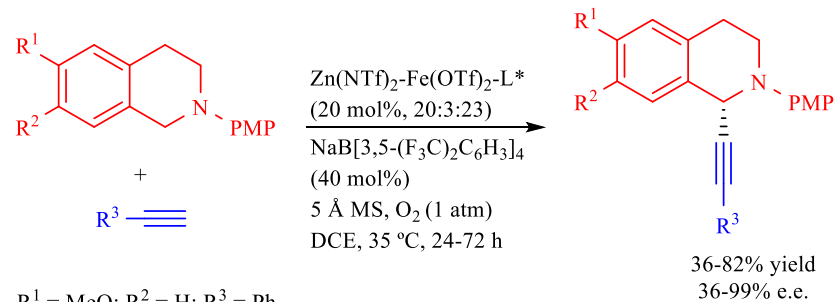

$\mathrm{R}^{1}=\mathrm{MeO} ; \mathrm{R}^{2}=\mathrm{H} ; \mathrm{R}^{3}=\mathrm{Ph}$ 36-99\% e.e.

$\mathrm{R}^{1}=\mathrm{R}^{2}=\mathrm{MeO}$ or $\mathrm{R}^{1}-\mathrm{R}^{2}=\mathrm{OCH}_{2} \mathrm{O} ; \mathrm{R}^{3}=\mathrm{Ph}$

$\mathrm{R}^{1}=\mathrm{R}^{2}=\mathrm{H} ; \mathrm{R}^{3}=\mathrm{Ph}, 4-\mathrm{YC}_{6} \mathrm{H}_{4}\left(\mathrm{Y}=\mathrm{Me}, \mathrm{Et}, \mathrm{Cl}, \mathrm{Br}, n\right.$-Pr, $n$-Bu, $n$-Pent, $\mathrm{MeO}, \mathrm{MeCO}_{2}$, $\mathrm{NC}), 2-\mathrm{YC}_{6} \mathrm{H}_{4}(\mathrm{Y}=\mathrm{F}, \mathrm{Cl}), 3-\mathrm{YC}_{6} \mathrm{H}_{4}\left(\mathrm{Y}=\mathrm{F}, \mathrm{Cl}, \mathrm{Me}, \mathrm{MeO}, \mathrm{O}_{2} \mathrm{~N}\right), 3,5-\mathrm{F}_{2} \mathrm{C}_{6} \mathrm{H}_{3}$, 1-naphthyl, 2-thienyl, $\mathrm{CH}_{2} \mathrm{CH}_{2} \mathrm{Ph}, c$ - $\mathrm{Pr}, n$-decyl, 1-phenylcyclopropyl,
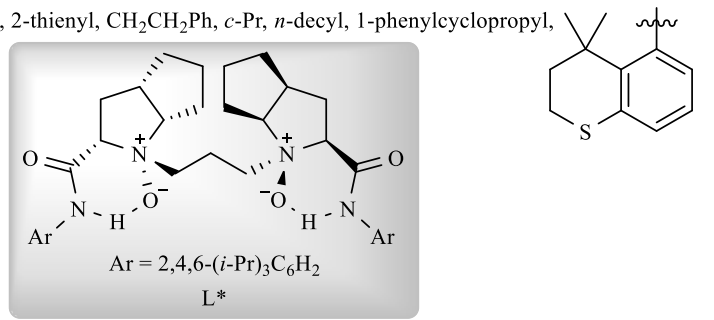

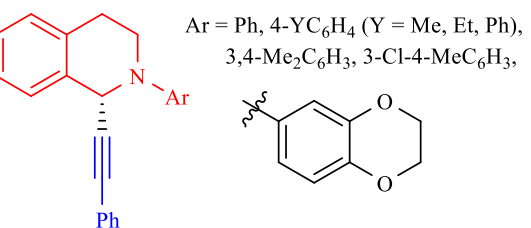

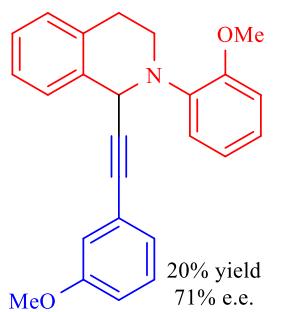

$60-65 \%$ yield $89-97 \%$ e.e.<smiles>COc1cccc(C#C[C@H]2c3ccccc3CCN2c2ccc(OC)cc2OC)c1</smiles><smiles>COc1ccc(N2CCc3cccc(Cl)c3C2C#Cc2ccccc2)cc1</smiles>

\section{Scheme 35}

Although most of the studies on the asymmetric synthesis of propargylamines by CDC have focused on THIQs as substrates, Liu et al. published a survey on the coppercatalyzed aerobic CDC of $\mathrm{N}$-aryl glycine esters and terminal alkynes [51]. The catalytic system was composed of $\mathrm{Cu}(\mathrm{OTf})_{2}$ and a Pybox-type chiral ligand which, in a first step reacted with the $N$-aryl glycine ester under molecular oxygen, whereas the alkyne was added in a second step under a nitrogen atmosphere. The resulting $\alpha$-alkynyl amino acid derivatives were produced in moderate-to-good yields and fair-to-high enantiomeric ratios, including those derived from aliphatic alkynes (Scheme 36 ). The aryl group bonded 
to the $\mathrm{N}$ atom was found to be decisive for the reaction to occur. The participation of a copper complex was suggested, in which the imino ester and the chiral ligand were coordinated to the metal of the copper acetylide.

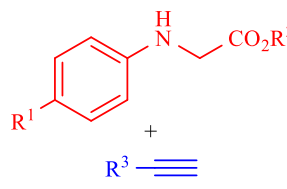

$\mathrm{R}^{1}=\mathrm{Me}, \mathrm{MeO}, \mathrm{Br}$ $\mathrm{R}^{2}=\mathrm{Et}, i$-Pr, $i$-Bu

$\mathrm{R}^{3}=\mathrm{Ph}, 4-\mathrm{YC}_{6} \mathrm{H}_{4}(\mathrm{Y}=\mathrm{Me}, \mathrm{MeO}, \mathrm{Cl}, \mathrm{Br}), 3-\mathrm{MeC}_{6} \mathrm{H}_{4}, n-\mathrm{Bu}$, $n$-Hex, $n$-Oct, $c$ - $\mathrm{Pr}, \mathrm{CH}_{2} \mathrm{CH}_{2} \mathrm{OTBS}, \mathrm{CH}_{2} \mathrm{CH}_{2} \mathrm{OBn}$

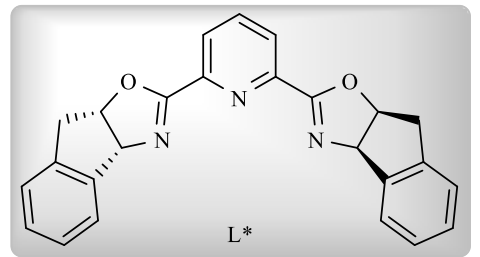

Scheme 36

\section{CONCLUSION}

Concluding this review, we can say that the CDC of amines and terminal alkynes is a convenient and green approach to the synthesis of propargylamines. The high atom economy of the process, without any pre-functionalization, makes of this coupling a competitive tool to make $\mathrm{NCsp}^{3}$-Csp bonds. Homogeneous catalytic CDC works with 5-40 mol\% catalyst at $60-110{ }^{\circ} \mathrm{C}$, commonly, for $\mathrm{N}, \mathrm{N}$-dimethyl-substituted anilines and benzylamines, in the presence of a peroxide, under an inert atmosphere in an organic solvent. The protocols involving air or molecular oxygen as the terminal oxidants are particularly interesting. The reaction has been upgraded in terms of sustainability by introducing heterogeneous catalysts, which are recyclable and work with lower metal loading (1-10 mol\%), albeit at higher temperature (mostly, $100-140{ }^{\circ} \mathrm{C}$ ). Reactions at room temperature have been performed through photoredox catalysis; this is an underdeveloped approach, so far conditioned to the use of expensive ruthenium complexes and applicable exclusively to tetrahydroisoquinolines. Moreover, the fact that propargylamines can be obtained in a chiral non-racemic fashion by asymmetric synthesis, makes this strategy additionally attractive. In our opinion, there is still room for research in this area, as some aspects are partially unresolved or pending solution. Further investigation should be focused on reducing the amount of catalyst (particularly in homogeneous catalysis), as well as on the use of environmentally benign solvents or solvent-free protocols under aerobic conditions, and on the activation of the more demanding unreactive aliphatic (non-benzylic) amines and alkynes. The exploration of metals other than copper and ruthenium in the catalytic systems might open new ventures in the synthesis of propargylamines by CDC.

*Address correspondence to this author at the Instituto de Síntesis Orgánica and Departamento de Química Orgánica, Facultad de Ciencias, Universidad de Alicante, Apdo. 99, 03080 Alicante, Spain; Tel/Fax: +34-965909614, +34-965903549; E-mail: falonso@ua.es

\section{LIST OF ABBREVIATIONS}

BDC: 1,4-benzenedicarboxylate

bpy: 2,2'-bipyridine

Cbz: benzyloxycarbonyl

CDC: Cross-Dehydrogenative Coupling

CPME: cyclopentyl methyl ether

DABCO: 1,4-diazabicyclo[2.2.2]octane

DEAD: diethyl azodicarboxylate

DMA: $N, N$-dimethylacetamide

dtbppy: 4,4'-di-tert-butyl-2,2'-bipyridine

equiv.: equivalent

$\mathrm{L}^{*}$ : chiral ligand

MAO-N: monoamine oxidase type $\mathrm{N}$

MS: molecular sieves

NBS: $N$-bromosuccinimide

OMS-2: oxide-based octahedral molecular sieve

PVP: $\operatorname{poly}(N$-vinylpyrrolidin-2-one)

Py: pyridine

Pybox: 2,6-bis[(4S)-4-phenyl-2-oxazolinyl]pyridine

TBHP: tert-butylhydroperoxide

TBP: tert-butylperoxide

THIQ: 1,2,3,4-tetrahydroisoquinoline

TMEDA: $N, N, N$ ', $N$ '-tetramethylethylenediamine

\section{CONFLICT OF INTEREST}

The authors declare no conflict of interests. The manuscript was written through contributions of all authors, who have given approval to the final version of the manuscript.

\section{ACKNOWLEDGEMENTS}

This work was generously supported by the Spanish Ministerio de Ciencia, Innovación y Universidades (MICIU; grant no. CTQ2017-88171-P), the Generalitat Valenciana (GV; grant no. AICO/2017/007) and the Instituto de Síntesis Orgánica (ISO). I.B. is also grateful to the Spanish MICIU for a Juan de la Cierva-incorporación grant (no. IJCI-201733706).

\section{REFERENCES}

[1] (a) Xiao, F.; Chen, Y.; Liu, Y.; Whang, J. Sequential catalytic process: synthesis of quinoline derivatives by $\mathrm{AuCl}_{3} / \mathrm{CuBr}$ catalyzed three-component reaction of aldehydes, amines, and alkynes. Tetrahedron, 2008, 64, 2755-2761. (b) Shibata, D.; Okada, E.; Molette, J.; Médebielle, M. Facile synthesis of fluorinecontaining 1,10-phenanthrolines by the pyridine-ring formation reaction of $N$-propargyl-5,7-bis(trifluoroacetyl)-8-quinolylamine with amines: isolation of the intermediates 1,4-dihydro-1,10phenanthrolin-4-ols. Tetrahedron Lett., 2008, 49, 7161-7164. (c) Yamamoto, Y.; Hayashi, H.; Saigoku, T.; Nishiyama, H. Domino coupling relay approach to polycyclic pyrrole-2-carboxylates. $J$. Am. Chem. Soc., 2005, 127, 10804-10805. (d) Harvey, D.F.; Sigano, D.M. Synthesis of cyclopropylpyrrolidines via reaction of $N$-allyl- $N$-propargylamides with a molybdenum carbene complex. Effect of substituents and reaction conditions. J. Org. Chem., 1996, 61, 2268-2272. (e) Albaladejo, M.J.; Alonso, F.; González-Soria, M.J. Synthetic and mechanistic studies on the solvent-dependent copper-catalyzed formation of indolizines and chalcones. ACS Catal., 2015, 5, 3446-3456. (f) Lee, E.-S.; Yeom, H.-S.; Hwang, J.-H.; Shin, S. A practical gold-catalyzed route to 4-substituted oxazolidin-2-ones from $\mathrm{N}$-Boc propargylamines. Eur. J. Org. Chem., 2007, 3503-3507.

[2] See, for instance: (a) Jiang, C.; Xu, M.; Wang, S.; Wang, H.; Yao, Z.-J. Azaanthraquinone assembly from $N$-propargylamino quinone via a $\mathrm{Au}(\mathrm{I})$-catalyzed 6-endo-dig cycloisomerization. J. Org. 
Chem., 2010, 75, 4323-4325. (b) Fañanás, F.J.; Arto, T.; Mendoza, A.; Rodríguez, F. Synthesis of 2,5-dihydropyridine derivatives by gold-catalyzed reactions of $\beta$-ketoesters and propargylamines. Org. Lett., 2011, 13, 4184-4187. (c) Symeonidis, T.S.; Kallitsakis, M.G., Litinas, K.E. Synthesis of [5,6]-fused pyridocoumarins through aza-Claisen rearrangement of 6-propargylaminocoumarins. Tetrahedron Lett., 2011, 52, 5452-5455. (d) Zhao, Y.L.; Di, C.-H.; Liu, S.-D.; Meng, J., Liu, Q. [3+2] Cycloaddition of propargylamines and $\alpha$-acylketene dithioacetals: a synthetic strategy for highly substituted pyrroles. Adv. Synth. Catal. 2012, 354, 3545-3550. (e) Wachenfeldt, H.V.; Paulsen, F.; Sundin, A.; Strand, D. Synthesis of substituted oxazoles from $N$-benzyl propargyl amines and acid chlorides. Eur. J. Org. Chem., 2013, 4578-3550. (d) Alcaide, B.; Almendros, P.; Alonso, J.M.; Fernández, I.; Campillos, G.G.; Torres, M.R. A gold-catalysed imine-propargylamine cascade sequence: synthesis of 3substituted-2,5-dimethylpyrazines and the reaction mechanism. Chem. Commun., 2014, 50, 4567-4567.

[3] Account: Nakamura, H. C $\left(\mathrm{sp}^{3}\right)-\mathrm{H}$ versus $\mathrm{C}\left(\mathrm{sp}^{3}\right)-\mathrm{C}(\mathrm{sp})$ in activation 26, 1649-1664.

[4] See, for instance: (a) Hoepping, A.; Johnson, K.M.; George, C.; Flippen-Anderson, J.; Kozikowski, A.P. Novel conformationally constrained tropane analogues by 6-endo-trig radical cyclization and Stille coupling-switch of activity toward the serotonin and/or norepinephrine transporter. J. Med. Chem., 2000, 43, 2064-2071. (b) Jiang, B.; Xu, M. Highly enantioselective construction of fused pyrrolidine systems that contain a quaternary stereocenter: concise formal synthesis of (+)-conessine. Angew. Chem. Int. Ed., 2004, 43, 2543-2546. (c) Fleming, J.J.; Du Bois, J. A synthesis of (+)saxitoxin. J. Am. Chem. Soc., 2006, 128, 3926-3927.

[5] See, for instance: (a) Review: Bar-Am, O.; Amit, T.; Weinreb, O.; Youdim, M.B.H.; Mandel, S. Propargylamine containing compounds as modulators of proteolytic cleavage of amyloid protein precursor: involvement of MAPK and PKC activation. $J$. Alheimer's Dis., 2010, 21, 361-371. (b) Review: Bolea, I.; Gella, A.; Unzeta, M. Propargylamine-derived multitarget-directed ligands: fighting Alzheimer's disease with monoamine oxidase inhibitors. J. Neural Transm., 2013, 120, 893-902. (c) Louvel, J.; Carvalho, J.F.S.; Yu, Z.; Soethoudt, M.; Lenselink, E.B.; Klaase, E.; Brussee, J.; Ijzerman, A.P. Removal of human ether-à-go-go related gene (hERG) $\mathrm{K}^{+}$channel affinity through rigidity: a case of clofilium analogues. J. Med. Chem., 2013, 56, 9427-9440. [6] (a) Olanow, C.W. Rationale for considering that propargylamines
might be neuroprotective in Parkinson's disease. Neurology, 2006, 66, S69-S79. (b) Naoi, M.; Maruyama, W.; Yi, H.; Akao, Y.; Yamaoka, Y.; Shamoto-Nagai, M. Neuroprotection by propargylamines in Parkinson's disease: intracellular mechanism underlying the anti-apoptotic function and search for clinical markers. J. Neural Transm. Suppl., 2007, 72, 121-131. (c) Review: Oldfield, V.; Keating, G.M.; Perry, C.M. Rasagiline: a review of its use in the management of Parkinson's disease. Drugs, 2007, 67, 1725-1747. (d) Murphy, D.L., Karoum, F.; Pickar, D.; Cohen, R.M.; Lipper, S.; Mellow, A.M.; Tariot, P.N.; Sunderland, T. Differential trace amine alterations in individuals receiving acetylenic inhibitors of MAO-A (clorgyline) or MAO-B (selegiline and pargyline). J. Neural Transm. Suppl., 1998, 52, 39-48. (e) Baranyi, M.; Porceddu, P.F.; Gölöncsér, F.; Kulcsár, S.; Otrokocsi, L.; Kittel, A.; Pinna, A.; Frau, L.; Huleatt, P.B.; Khoo, M.-L.; Chai, C.L L.; Dunkel, P.; Mátyus, P.; Morelli, M.; Sperlágh, B. Novel (hetero)arylalkenyl propargylamine compounds are protective in toxin-induced models of Parkinson's disease. Mol. Neurodegener., 2016, 11, 1-21.

[7] (a) Kopka, I.E.; Fataftah, Z.A.; Rathke, M.W. Preparation of a series of highly hindered secondary amines, including bis(triethylcarbinyl)amine. J. Org. Chem., 1980, 45, 4616-4622. (b) Czernecki, S.; Valéry, J.-M. A stereocontrolled synthesis of a lincosamine precursor. J. Carbohydr. Chem., 1990, 9, 767-770. (c) Imada, I.; Yuasa, M.; Nakamura, I.; Murahashi, S.-I. Copper(I)catalyzed amination of propargyl esters. Selective synthesis of propargylamines, 1-alken-3-ylamines, and (Z)-allylamines. J. Org. Chem., 1994, 59, 2282-2284.

[8] For reviews, see: (a) Bloch, R. Additions of organometallic reagents to $\mathrm{C}=\mathrm{N}$ bonds: reactivity and selectivity. Chem. Rev., 1998, 98, 1407-1438. (b) Kouznetsov, V.V.; Vargas Méndez, L.Y. Recent developments in three-component Grignard-Barbier-type reactions. Synthesis, 2008, 491-506. (c) Blay, G., Monleón, A.;
Pedro, J.R. Recent developments in asymmetric alkynylation of imines. Curr. Org. Chem., 2009, 13, 1498-1539. See also: (d) Fischer, C., Carreira, E.M. Direct addition of TMS-acetylene to aldimines catalyzed by a simple, commercially available $\operatorname{Ir}(\mathrm{I})$ complex. Org. Lett., 2001, 3, 4319-4321. (e) Fischer, C.; Carreira, E.M. Zn-alkynylide additions to acyl iminiums. Org. Lett., 2004, 6, 1497-1499.

[9] For reviews, see: (a) Wei, C.; Li, Z.; Li, C.-J. The development of $\mathrm{A}^{3}$-coupling (aldehyde-alkyne-amine) and $\mathrm{AA}^{3}$-coupling (asymmetric aldehyde-alkyne-amine). Synlett, 2004, 1472-1483. (b) Zani, L.; Bolm, C. Direct addition of alkynes to imines and related $\mathrm{C}=\mathrm{N}$ electrophiles: a convenient access to propargylamines. Chem. Commun., 2006, 4263-4275. (c) Li, C.-J. The development of catalytic nucleophilic additions of terminal alkynes in water. Acc. Chem. Res., 2010, 43, 581-590. (d) Yoo, W.-J.; Zhao, L.; Li, C.-J. The $\mathrm{A}^{3}$-coupling (aldehyde-alkyne-amine) reaction: a versatile method for the preparation of propargylamines. Aldrichim. Acta, 2011, 44, 43-51. (e) Yoo, W.-J.; Zhao, L.; Li, C.-J. In: Science of Synthesis; Mueller, T.J., Ed.; Thieme: Stuttgart, 2014; Vol. 1, pp. 189-217. See also: (f) Albaladejo, M.J.; Alonso, F.; Moglie, Y.; Yus, M. Three-component coupling of aldehydes, amines, and alkynes catalyzed by oxidized copper nanoparticles on titania. Eur. J. Org. Chem. 2012, 3093-3104. (g) Das, D.; Sun, A. X.; Seidel, D. Redox-neutral copper(II) carboxylate catalyzed $\alpha$ alkynylation of amines. Angew. Chem. Int. Ed., 2013, 52, 37653769. (h) Zheng, Q.-H.; Meng, W.; Jiang, G.-J.; Yu, Z.-Y. CuIcatalyzed C1-alkynylation of tetrahydroisoquinolines (THIQs) by $\mathrm{A}^{3}$ reaction with tunable iminium ions. Org. Lett., 2013, 15, 59285931.

[10] (a) Xu, X.; Ge, Z.; Cheng, D.; Li, X. Functionalization of aliphatic tertiary amines mediated by hexachloroethane/cat. copper: synthesis of propargylic amines and methylene-bridged bis-1,3dicarbonyl derivatives. ARKIVOC, 2012, viii, 107-118. (b) Chen, X.; Chen, T.; Zhou, Y.; Au, C.-T.; Han, L.-B.; Yin, S.-F. Efficient synthesis of propargylamines from terminal alkynes, dichloromethane and tertiary amines over silver catalysts. Org. Biomol. Chem., 2014, 12, 247-250.

[11] (a) Glaser, C. Beiträge zur kenntniss des acetenylbenzols. Ber. Dtsch. Chem. Ges., 1869, 2, 422-424. (b) Eglinton, G.; Galbraith, A. R. Cyclic diynes. Chem. Ind., 1956, 737-738. (c) Hay, A. S Oxidative coupling of acetylenes. J. Org. Chem., 1962, 27, 33203321.

[12] Reviews: (a) Li, C.-J. Cross-dehydrogenative coupling (CDC): exploring $\mathrm{C}-\mathrm{C}$ bond formations beyond functional group transformations. Acc. Chem. Res., 2009, 42, 335-344. (b) Scheuermann, C.J. Beyond traditional cross couplings: the scope of the cross dehydrogenative coupling reaction. Chem. Asian J., 2010 , 5, 436-451. (c) Yeung, C.S.; Dong, V.M. Catalytic dehydrogenative cross-coupling: forming carbon-carbon bonds by oxidizing two carbon-hydrogen bonds. Chem. Rev., 2011, 111, 1215-1292. (d) Le Bras, J.; Muzart, J. Intermolecular dehydrogenative Heck reactions. Chem. Rev., 2011, 111, 11701214. (e) Patureau, F. W.; Wencel-Delord, J.; Glorius, F. Cp*Rhcatalyzed $\mathrm{C}-\mathrm{H}$ activations: versatile dehydrogenative crosscouplings of $\mathrm{Csp}^{2} \mathrm{C}-\mathrm{H}$ positions with olefins, alkynes, and arenes. Aldrichim. Acta, 2012, 45, 31-41. (f) Girard, S.A.; Knauber, T.; Li, C.-J. The cross-dehydrogenative coupling of $\mathrm{C}\left(\mathrm{sp}^{3}\right)-\mathrm{H}$ bonds: a versatile strategy for $\mathrm{C}-\mathrm{C}$ bond formations. Angew. Chem. Int. Ed., 2014, 53, 74-100. (g) From $C-H$ to $C-C$ Bonds: CrossDehydrogenative-Coupling; Li, C.-J. Ed.; RSC: Cambridge (UK), 2015. (h) Xia, J.-B.; Lou, S.-L. In: Catalytic Transformations via C-H Activation; Science of Synthesis; Yu, J.-Q. Ed.; Thieme: Sttutgart, 2016, Vol. 2, pp. 115-136. (i) Lv, L.; Li, Z. Fe-catalyzed cross-dehydrogenative coupling reactions. Top. Curr. Chem., 2016, 374:38. (j) Varun, B.V.; Dhineshkumar, J.; Bettadapur, K.R.; Siddaraju, Y.; Alagiri, K.; Prabhu, K.R. Recent advancements in dehydrogenative cross coupling reactions for $\mathrm{C}-\mathrm{C}$ bond formation. Tetrahedron Lett., 2017, 58, 803-824.

[13] Murata, S.; Teramoto, K.; Miura, M.; Nomura, M. Coppercatalysed oxidative coupling of 4-substituted $\mathrm{N}, \mathrm{N}$-dimethylanilines with terminal alkynes under molecular oxygen. J. Chem Res. (M), 1993, 2828-2836.

[14] (a) Li, Z.; Li, C.-J. CuBr-catalyzed efficient alkynylation of $\mathrm{sp}^{3} \mathrm{C}-$ $\mathrm{H}$ bonds adjacent to a nitrogen atom. J. Am. Chem. Soc., 2004, 126, 11810-11811. (b) Li, Z.; Bohle, D.S.; Li, C.-J. Cu-catalyzed crossdehydrogenative coupling: a versatile strategy for C-C bond 
formations via the oxidative activation of $\mathrm{sp}^{3} \mathrm{C}-\mathrm{H}$ bonds. Proc. Natl. Acad. Sci., 2006, 103, 8928-8933.

[15] Niu, M.; Yin, Z.; Fu, H.; Jiang, Y.; Zhao, Y. Copper-catalyzed coupling of tertiary aliphatic amines with terminal alkynes to propargylamines via $\mathrm{C}-\mathrm{H}$ activation. J. Org. Chem., 2008, 73, 3961-3963.

[16] Gupta, S.; Dubey, P.; Singh, A. K.; Jain, N. Oxidative C-C bond formation and $\mathrm{C}-\mathrm{N}$ bond cleavage catalyzed by complexes of copper(I) with acridine based $(\mathrm{E} \mathrm{N}$ E) pincers $(\mathrm{E}=\mathrm{S} / \mathrm{Se})$, recyclable as a catalyst. Dalton Trans., 2019, 48, 10129-10137.

[17] Xu, X.; Li, X. Copper/diethyl azodicarboxylate mediated regioselective alkynylation of unactivated aliphatic tertiary methylamine with terminal alkyne. Org. Lett., 2009, 11, 10271029.

[18] Shen, Q.; Zhang, L.; Zhou, Y.-R.; Li, J.-X. Oxidant-dependent Cucatalyzed alkynylation and aminomethylation: $\mathrm{C}-\mathrm{H}$ versus $\mathrm{C}-\mathrm{C}$ cleavage in TMEDA. Tetrahedron Lett., 2013, 54, 6725-6728.

[19] Xu, Z.; Yu, X.; Feng, X.; Bao, M. Propargylamine synthesis by copper-catalyzed oxidative coupling of alkynes and tertiary amine $N$-oxides. J. Org. Chem., 2011, 76, 6901-6905.

[20] Rao, C. M.; Vogel, P. Chemoselective C-H bond activation: ligand and solvent-free iron-catalyzed oxidative C-C cross coupling of tertiary amines with terminal alkynes. Reaction scope and mechanism. Org. Lett., 2009, 11, 1701-1704.

[21] Sugiishi, T.; Nakamura, H. Zinc(II)-catalyzed redox crossdehydrogenative coupling of propargylic amines and terminal alkynes for synthesis of $N$-tethered 1,6-enynes. J. Am. Chem. Soc., 2012, 134, 2504-2507.

[22] Jin, X.; Yamaguchi, K.; Mizuno, N. Aerobic cross-dehydrogenative coupling of terminal alkynes and tertiary amines by a combined catalyst of $\mathrm{Zn}^{2+}$ and OMS-2. RSC Adv., 2014, 4, 34712-34715.

[23] Short review: San Segundo, M.; Correa, A. Cross-dehydrogenative coupling reactions for the functionalization of $\alpha$-amino acid derivatives and peptides Synlett, 2018, 50, 2853-2866.

[24] Zhao, L.; Li, C.-J. Functionalizing glycine derivatives by direct CC bond formation. Angew. Chem. Int. Ed., 2008, 47, 7075-7078.

[25] Liu, P.; Wang, Z.; Lin, J.; Hu, X. An efficient route to quinolines and other compounds by iron-catalyzed cross-dehydrogenative coupling reactions of glycine derivatives. Eur. J. Org. Chem., 2012, 1583-1589.

[26] (a) Miniperspective: Vitaku, E.; Smith, D.T.; Njardarson, T. Analysis of the structural diversity, substitution patterns, and frequency of nitrogen heterocycles among U.S. FDA approved pharmaceuticals. J. Med. Chem., 2014, 57, 10257-10274. (b) Yet, L. Priviledged Structures in Drug Discovery: Medicinal Chemistry and Synthesis, 1st. ed.; Wiley \& Sons: Hoboken, NJ, 2018; Chapter 10 , pp. 356-410

[27] Zimmerman, T.J.; Roy, S.; Martinez, N.E.; Ziegler, S.; Hedberg, C.; Waldmann, H. Biologically-oriented synthesis of tetrahydroisoquinoline-based compound collection microtubule polymerization. ChemBioChem, 2013, 14, 295-300.

[28] Gröll, B.; Schaff, P.; Schnürch, M. Improved simplicity and practicability in copper-catalyzed alkynylation of tetrahydroisoquinolines. Monatsh. Chem., 2017, 148, 91-104.

[29] Boess, E.; Schmitz, C.; Klussmann, M. A comparative study of $\mathrm{Cu}-$ catalyzed oxidative coupling reactions with $\mathrm{N}$ phenyltetrahydroisoquinoline. J. Am. Chem. Soc., 2012, 134, 53175325.

[30] Odachowski, M.; Greaney, M.F.; Turner, N.J. Concurrent biocatalytic oxidation and $\mathrm{C}-\mathrm{C}$ bond formation via gold catalysis: one-pot alkynylation of $\mathrm{N}$-alkyl tetrahydroisoquinolines. ACS Catal., 2018, 8, 10032-10035.

[31] Review: Descorme, C.; Gallezot, P.; Geantet, C.; George, C. Heterogeneous catalysis: a key tool toward sustainability. ChemCatChem, 2012, 4, 1897-1906.

[32] Liu, P.; Zhou, C.-Y.; Xiang, S.; Che, C.-M. Highly efficient oxidative carbon-carbon coupling with SBA-15-support iron terpyridine catalyst. Chem. Commun., 2010, 46, 2739-2741.

[33] Hudson, R.; Ishikawa, S.; Moores, A. Magnetically recoverable $\mathrm{CuFe}_{2} \mathrm{O}_{4}$ nanoparticles as highly active catalysts for $\mathrm{Csp}^{3}-\mathrm{Csp}$ and $\mathrm{Csp}^{3}-\mathrm{Csp}^{3}$ oxidative cross-dehydrogenative coupling. Synlett, 2013, 24, 1637-1642.

[34] Dang, G.H.; Nguyen, D.T.; Le, D.T.; Phan, N.T.S. Propargylamine synthesis via direct oxidative C-C coupling reaction between $\mathrm{N}, \mathrm{N}$ dimethylanilines and terminal alkynes under metal-organic framework catalysis. J. Mol. Catal. A: Chem., 2014, 395, 300-306.
[35] Dang, G.H.; Dang, T.T.; Le, D.T.; Truong, T.; Phan, N.T.S Propargylamine synthesis via sequential methylation and $\mathrm{C}-\mathrm{H}$ functionalization of $\mathrm{N}$-methylanilines and terminal alkynes under metal-organic framework $\mathrm{Cu}_{2}(\mathrm{BDC})_{2}(\mathrm{DABCO})$ catalysis. J. Catal. 2014, 319, 258-264.

[36] Nguyen, A.; Pham, L.T.; Truong, T. Efficient and robust superparamagnetic copper ferrite nanoparticle-catalyzed sequential methylation and $\mathrm{C}-\mathrm{H}$ activation: aldehyde-free propargylamine synthesis. Catal. Sci. Technol., 2014, 4, 4281-4288.

[37] Alonso, F.; Arroyo, A.; Martín-García, I.; Moglie, Y. Crossdehydrogenative coupling of tertiary amines and terminal alkynes catalyzed by copper nanoparticles on zeolite. Adv. Synth. Catal., 2015, 357, 3549-3561

[38] Gupta, S.; Joshi, H.; Jain, N.; Singh, A.K. $\mathrm{Cu}_{6} \mathrm{Se}_{4.5}$ nanoparticles from a single source precursor: recyclable and efficient catalyst for cross-dehydrogenative coupling of tertiary amines with terminal alkynes. J. Mol. Catal. A: Chem., 2016, 423, 135-142.

[39] Dang-Bao, T.; Pradel, C.; Favier, I.; Gómez, M. Making Cu(0) nanoparticles in glycerol: a straightforward synthesis for a multipurpose catalyst. Adv. Synth. Catal., 2017, 359, 2832-2846.

[40] Selected recent reviews: (a) Staveness, D.; Bosque, I.; Stephenson, C. Free radical chemistry enabled by visible light-induced electron transfer. Acc. Chem. Res., 2016, 49, 2295-2306. (b) Xie, J.; Jin, H.; Hashmi, A.S.K. The recent achievements in redox-neutral radical C-C cross-coupling enabled by visible light. Chem. Soc. Rev., 2017, 46, 5193-5203; (c) Twilton, J.; Li, C. (Chip), Zhan, P.; Shaw, M.H.; Evans, R.W.; MacMillan, D.W.C. The merger of transition metal catalysis and photocatalysis. Nat. Rev. Chem., 2017, 1, 0052; (d) McLean, E.B.; Lee, A. Dual copper- and photoredox-catalysed reactions. Tetrahedron, 2018, 74, 4881-4902; (e) Merging transition-metal catalysis with photoredox catalysis: an environmentally friendly strategy for $\mathrm{C}-\mathrm{H}$ functionalization. Synthesis, 2018, 50, 3359-3378. (f) Hossain, A.; Bhattacharyya, A.; Reiser, O. Copper's rapid ascent in visible-light photoredox catalysis. Science, 2019, 364, eaav9713.

[41] Freeman, D.B.; Furst, L.; Condie, A.G.; Stephenson, C.R.J. Functionally diverse nucleophilic trapping of iminium intermediates generated utilizing visible light. Org. Lett., 2012, 14 , 94-97.

[42] Tucker, J.W.; Zhang, Y.; Jamison, T.F.; Stephenson, C.R.J. Visible-light photoredox catalysis in flow. Angew. Chem. Int. Ed., 2012, 51, 4144-4147.

[43] Rueping, M.; Koenigs, R.M.; Poscharny, K.; Fabry, D.C.; Leonori, D.; Vila, C. Dual catalysis: combination of photocatalytic aerobic oxidation and metal catalyzed alynylation reactions-C-C bond formation using visible light. Chem. Eur. J., 2012, 18, 5170-5174

[44] Review: Liu, J.; Dasgupta, S.; Watson, M.P. Enantioselective additions of copper acetylides to cyclic iminium and oxocarbenium ions. Beilstein J. Org. Chem., 2015, 11, 2696-2706.

[45] (a) Li, Z.; Li, C.-J. Catalytic enantioselective alkynylation of prochiral $\mathrm{sp}^{3} \mathrm{C}-\mathrm{H}$ bonds adjacent to a nitrogen atom. Org. Lett., 2004, 6, 4997-4999. (b) Li, Z.; MacLeod, P. D.; Li, C.-J. Studies on $\mathrm{Cu}$-catalyzed asymmetric alkynylation of tetrahydroisoquinoline derivatives. Tetrahedron: Asymmetry, 2006, 17, 590-597.

[46] Yu, J.; Li, Z.; Jia, K.; Jiang, Z.; Liu, M.; Su, W. Fast, solvent-free asymmetric alkynylation of prochiral $\mathrm{sp}^{3} \mathrm{C}-\mathrm{H}$ bonds in a ball mill for the preparation of optically active tetrahydroisoquinoline derivatives. Tetrahedron Lett., 2013, 54, 2006-2009.

[47] Sun, S.; Li, C.; Floreancig, P.E.; Lou, H.; Liu, L. Highly enantioselective catalytic cross-dehydrogenative coupling of $\mathrm{N}$ carbamoyl tetrahydroisoquinolines and terminal alkynes. Org. Lett., 2015, 17, 1684-1687.

[48] Perepichka, I.; Kundu, S.; Hearne, Z.; Li, C.-J. Efficient emerging of copper and photoredox catalysis for the asymmetric crossdehydrogenative coupling of alkynes and tetrahydroisoquinolines. Org. Biomol. Chem., 2015, 13, 447-451.

[49] Kumar, G.; Verma, S.; Ansari, A.; Khan, N. H.; Kureshy, R. I. Enantioselective cross dehydrogenative coupling reaction catalyzed by Rose Bengal incorporated-Cu(I)-dimeric chiral complexes. Catal. Commun., 2017, 99, 94-99.

[50] Huang, T.; Liu, X.; Lang, J.; Xu, J.; Lin, L.; Feng, X. Asymmetric aerobic oxidative cross-coupling of tetrahydroisoquinolines with alkynes. ACS Catal., 2017, 7, 5654-5660.

[51] Xie, Z.; Liu, X.; Liu, L. Copper-catalyzed aerobic enantioselective cross-dehydrogenative cooupling of $\mathrm{N}$-aryl glycine esters with terminal alkynes. Org. Lett., 2016, 18, 2982-2985. 
